\title{
Drug Management of Visceral Pain: Concepts from Basic Research
}

\author{
Mellar P. Davis ${ }^{1,2}$ \\ ${ }^{1}$ Cleveland Clinic Lerner School of Medicine, Case Western Reserve University, Cleveland, OH 44195, USA \\ ${ }^{2}$ Solid Tumor Division, Harry R. Horvitz Center for Palliative Medicine, Taussig Cancer Institute, USA
}

Correspondence should be addressed to Mellar P. Davis, davism6@ccf.org

Received 12 December 2011; Accepted 13 February 2012

Academic Editor: Sebastiano Sebastiano

Copyright (C) 2012 Mellar P. Davis. This is an open access article distributed under the Creative Commons Attribution License, which permits unrestricted use, distribution, and reproduction in any medium, provided the original work is properly cited.

\begin{abstract}
Visceral pain is experienced by $40 \%$ of the population, and $28 \%$ of cancer patients suffer from pain arising from intra- abdominal metastasis or from treatment. Neuroanatomy of visceral nociception and neurotransmitters, receptors, and ion channels that modulate visceral pain are qualitatively or quantitatively different from those that modulate somatic and neuropathic pain. Visceral pain should be recognized as distinct pain phenotype. TRPV1, Na 1.8, and ASIC3 ion channels and peripheral kappa opioid receptors are important mediators of visceral pain. Mu agonists, gabapentinoids, and GABAB agonists reduce pain by binding to central receptors and channels. Combinations of analgesics and adjuvants in animal models have supra-additive antinociception and should be considered in clinical trials. This paper will discuss the neuroanatomy, receptors, ion channels, and neurotransmitters important to visceral pain and provide a basic science rationale for analgesic trials and management.
\end{abstract}

\section{Introduction}

Normal individuals do not perceive signals emanating from their intestinal tract; however, enteric and extrinsic visceral afferents become hypersensitive in pain-processing disorders such as functional bowel syndromes or in diseases associated with inflammation such as inflammatory bowel disease and pancreatitis. Both inflammatory bowel disease and cancer-related metastases to viscera may produce persistent pain despite resolution of the underlying disease state [1]. Unexplained abdominal pain accounts for $40 \%$ of gastroenterology practice in the United Kingdom. Most abdominal pain is due to functional gastrointestinal disorders; irritable bowel syndrome, and functional dyspepsia [2]. Ten to $40 \%$ of the normal population will have complaints of abdominal cramps or pain. Most use over-the-counter medications usually antispasmodics and or antacids [3]. Inflammatory bowel disease causes visceral hypersensitivity, intestinal stenosis, anorectal urgency, fistula, and abscess. One-third to half of individuals with inflammatory bowel will have disabling visceral symptoms such as pain or colic or symptoms that resemble the irritable bowel syndrome $[4,5]$. Individuals with Crohn's disease in remission frequently have irritable bowel syndrome symptoms as a result of persistent visceral hypersensitivity which may mislead both patients and clinicians to believe that the Crohn's disease is active [6-9]. Hence, distinguishing functional from organic visceral pain can be a challenge. The duration of pain is longer with functional bowel disorders, whereas organic etiologies produce nocturnal pain and are frequently associated with weight loss and constitutional symptoms [3].

Visceral pain accounts for $28 \%$ of cancer-related pain. It is often accompanied by other pains such as neuropathic or somatic pain. Visceral pain in cancer patients may also be the result of treatment complications or comorbid diseases [10]. Causes of cancer-related visceral pain include hepatic metastases with extension to the hepatic capsule, biliary obstruction, pancreatitis as well as pancreatic primaries and peripancreatic nodal enlargement, retroperitoneal adenopathy from metastases, and visceral organ obstruction such as small bowel or colon obstruction, mesenteric infiltration, and peritoneal implants of cancer. Complications include not only intestinal obstruction by perforation and intussusceptions, but also visceral pain is described as pressurelike, intermittently squeezing or cramp, not well localized, vague in character, and difficult for patients to describe. 
TABLE 1: Distinctive features of visceral spinal afferents relative to somatic.

(1) Dual extrinsic afferent system

(2) Convergence of afferents on somatic and other visceral afferents within the spinal cord

(3) Widely overlapping receptive fields

(4) Dichotomization of fibers where a single neuron innervates two viscera

(5) Collateral activation of autonomic and enteric nervous system

(6) Larger cell bodies within dorsal root ganglia

(7) Wide overlapping receptor fields

(8) Lack of specialized nerve terminals

(9) First-order afferents arborize over several spinal segments

Greater expression of transient receptor potential $\left(\mathrm{TRPV}_{1}\right)$, sodium (Na 1.8), acid (ASIC3) ion channels, and calcitonin gene-related protein (CGRP)

(11) Limited number of stimulus responses (distension, ischemia, and inflammation)

(12) More discrete location of first-order terminals within the spinal cord (superficial dorsal horn, lamina V, and central)

(13) Afferents ascend with parasympathetic and sympathetic neuronal projections

(14) Viscerovisceral hyperalgesia and hypersensitivity

(15) Visceromotor responses and referred pain to somatic sites innervated by the samespinal cord level

(16) Second-order afferents ascend in the dorsal column

(17) Nonsomatotopically arranged input in dorsal column and central lateral thalamus unlike the lateral spinothalamics

(18) Poor representation in S1 cortex

(19) Greater emotional and autonomic responses to pain than somatic pain

Visceral pain is frequently accompanied by nausea, vomiting, and sweating. Pain, particularly if severe, is often referred to distant somatic (superficial) sites [11]. Treatment recommendations for visceral pain have been the same for somatic pain, yet visceral pain processing is distinctly different from somatic nociception and as a result should perhaps be treated differently from somatic pain (Table 1).

\section{Neuroanatomy}

2.1. Vagus Innervation. This sensory system of the gastrointestinal tract consists of intrinsic (enteric) sensory afferents and extrinsic (vagus, spinal, and pelvic) afferents. The intrinsic system functions independently of the CNS. Neurons are directly exposed mechanical forces and the chemical environment which is unlike somatic afferents neurons. Enterochromaffin cells within the mucosa and enteroendocrine cells release serotonin, cholecystokinin, orexin, and leptin which modulates and regulates motor activity [12]. The submucosal enteric plexus and myenteric plexus have a high degree of synaptic interactions which can be either inhibitory or stimulatory for the purpose of regulating gastrointestinal motility and peristalsis. Both plexuses received input from parasympathetic and sympathetic efferents. Vagal afferents are largely made up of neurons which interact with the submucosal and myenteric plexus and allow "crosstalk" between intrinsic and extrinsic systems [12]. The intrinsic system contains ganglia and interstitial cells of Cajal which act as pacemakers and gauges for muscle tension. Certain ion channels such as the transient receptor potential (TRP) group of ion channels which have a major role in pain processing are not found on intrinsic enteric neurons [12].
The vagus receives input largely from the mucosa and muscle enteric afferents as do the pelvic extrinsic afferents. Cell bodies of the vagus are found in the jugular and nodose ganglia; both ganglia are morphologically, biochemically, and functionally different from one another. Expression of ion channels and signal transduction are distinctly different between the two ganglia [12]. Vagal sensory afferents outnumber efferents 10 to 1 in both ganglia. Both project to the nucleus tractus solitarius [13]. From the nucleus tractus solitarius, second-order afferents project to the parabrachial nucleus and thalamus. Vagal neurons process physiologic information such as the nature and content of luminal constituents and presence or absence of motor activity and in response generate nonpain but potentially noxious symptoms such as nausea, vomiting, and early satiety [13]. Vagal afferent terminals are found in close proximity to enterochromaffin cells and are responsive to regional serotonin by way of certain serotonin (5HT1 5HT 3, 5HT4, and 5HT7) receptors. Ghrelin, released from gastric endocrine cells, binds to receptors on the vagus and nodose ganglia. Ghrelin blocks mucosal and muscle enteric afferents which are mechanically sensitive influencing motility, satiety, gastric emptying, and proximal stomach relaxation. The subjective result is increased appetite and meal volume $[14,15]$. Stomach distention, cholecystokinin, and leptin (which bind to receptors on the vagus and nodose ganglia) produce satiety and reduced nutritional intake [16-18]. Also found on intrinsic enteric neurons are mu and kappa opioid receptors. Activation of $\mathrm{mu}$ receptors inhibits peristalsis, stimulates circular muscle segmentation, reduces intraluminal secretion, and increases fluid absorption from the bowel lumen $[19,20]$. The use of mu agonists for visceral pain will 
therefore have an adverse effect on gastrointestinal motility and may increase patient symptom burden. Vagus muscle mechanicoreceptors are low threshold which elicit maximum firing rates within physiologic distention pressures and differ from extrinsic spinal afferents [21]. The mechanicoreceptors consist of "in-series-tension" receptors between longitudinal and circular muscle and intraganglionic laminar endings which are intimately arrayed around enteric ganglia. Both in series-tension receptors and laminar endings contain nonencapsulated low-threshold sensors with primitive endings responsive to nonnoxious physiologic stimuli $[12,21,22]$.

2.2. Spinal Afferents. Extrinsic spinal visceral afferents located in the serosa and mesentery ascend to the thoracolumbar dorsal root ganglia with parasympathetic and sympathetic fibers [21]. A large battery of pain mediators (protons, prostaglandins, interleukins anti-inflammatory cytokines, and bradykinin) are released as a result of visceral inflammation, hollow organ distention or distortion, and ischemia. These mediators bind to various ion channels or receptors found on spinal afferents. Certain channels such as the transient receptor potential ion channels (TRP), acids sensing ion channels (ASIC), and sodium channels ( $\mathrm{Na}$ ) are activated resulting in an action potential. Hence, spinal visceral afferents have promiscuous chemosensitivity [13, $21,23]$. Visceral spinal afferents have a distinctive large cell body relative to somatic afferents visualized within the dorsal root ganglia. Visceral afferents makeup $7 \%$ of sensory cell bodies within the dorsal root ganglion [13, 23]. A significant proportion of visceral spinal afferents are high-threshold or silent nociceptors which respond selectively to noxious stimuli. Spinal visceral afferent action potentials propagate centrifugal and centripetal along collaterals resulting in the release of neurotransmitters, mainly calcitonin gene-related protein (CGRP) and substance P (SP) from varicose nerve terminals which in turn modulate blood flow and enteric motor reflexes; the end result is a neurogenic inflammatory response [13, 23]. Visceral spinal afferents converge on somatic afferents within the dorsal root ganglia and dorsal horn which is thought to be the mechanism for somatic referred pain [24, 25]. Convergence also occurs among visceral afferents within the same dorsal horn segment resulting in a viscerovisceral convergence and hyperalgesia [25]. In animal models, visceral pain causes a visceromotor response observed in anterior abdominal wall musculature as a result of convergence which is used as an objective measure of nociception. This can be elicited by experimental colitis, acetic acid peritonitis, or colorectal distention. Visceral convergence leads to cross-organ sensitization in which disease in one visceral organ increases the pain arising from another visceral organ innervated by the same spinal segment $[22,24$, $25]$. As an example, in mice and rats, experimental colitis increases bladder sensitivity and contractions [26]. Clinical individuals with irritable bowel syndrome have a greater incidence of urinary bladder sensitivity compared with the normal population [27]. Another mechanism proposed for viscerovisceral sensitivity is dichotomized sensory fibers in which one afferent neuron innervates two visceral organs $[28,29]$. Another proposed mechanism is generation of retrograde action potentials via viscerovisceral convergence leading to upregulation of neurotransmitters and ion channels in the second visceral organ [30,31]. Finally, visceral afferents travel with parasympathetic and sympathetic fibers which activate afferents within autonomic ganglia by way of collaterals resulting in an autonomic and motor response in the second visceral organ [32]. Spinal visceral afferents have large overlapping receptive fields relative to somatic afferents and sparse innervation relative to somatic tissues. Because of the anatomical differences and convergence, visceral pain is poorly localized, diffuse, and frequently identified by its somatic referral pattern. Viscerovisceral hypersensitivity can lead to diagnostic dilemmas as to where the pathology is occurring or misdiagnosis of the origin of visceral pain [12]. Somatic convergence can lead to inhibitory or excitatory responses. A counterirritation can produce an inhibitory response at either somatic or visceral site. Inhibitory responses from convergence can last as long as one second and may account for the colicky nature of visceral pain [33]. Patients often use counterirritation at referred somatic sites that reduce visceral pain [33].

Second-order visceral afferents ascend the thoracolumbar spinal cord through the dorsal column to gracile and cuneate nuclei. As a result, an anatomical cervical midline myelotomy interrupts dorsal column secondary afferent neurotransmission and reduces visceral pain and nocifensive responses in animal with pancreatic and duodenal pain [3436]. Third-order afferents ascend to the ventral posterolateral and central lateral nucleus of the thalamus $[37,38]$. The central lateral nucleus is the major site for medial afferents traffic important to emotive pain responses. Visceral afferents are highly represented in the medial pain matrix (insular cortex, prefrontal cortex, and anterior cingulate gyrus) which is responsible for the large emotional response to visceral pain. Visceral afferents are sparsely represented in S1 cortex; hence, visceral pain is poorly localizable by patients. The anterior cingulate gyrus is critical to downward modulating pain through the periaqueductal gray and rostral ventromedial medulla (RVM) [39]. The RVM has been demonstrated to exert descending facilitatory influences in visceral pain process and is a critical compound to the maintenance of pain from visceral inflammation $[40,41]$.

\section{Important Channels, Receptors, and Mediators of Visceral Pain}

Several channels are important to visceral pain: transient receptor potential vanilloid-1 (TRPV-1), ASIC3 channels and sodium channels (Na) particularly those that are tetrodotoxin resistant (NA 1.8 and 1.9), and calcium channels. Certain receptors downmodulate pain: the gamma aminobutyric acid-B (GABA-B) channels, kappa and mu opioid receptors, and somatostatin receptors. These channels and receptors are potential targets for novel analgesics to treat visceral pain.

3.1. Transient Receptor Potential Ion Channels. The TRP family of ion channels is TRPV1, TRPV2, TRPV3, TRPV4, 
TRPM 8, and TRPA1. These channels are, in general, thermoreceptors found on poorly myelinated and nonmyelinated afferents arising from the dorsal root ganglia, nodose ganglia, and the CNS [42-46]. TRP channels also respond to nonnoxious heat (TRPV3, TRPV4, and TRPM8), capsaicin (TRPV1), methanol (TRPM8) camphor (TRPV3), mustard (TRPA1), protons (TRPV1) and the endogenous cannabinoid, and anandamide (TRPV1) [46]. These channels are calcium permeable, nonselective channels with 4 identical subunits and a central pore. Each subunit consists of a 6 transmembrane (TM) segments with an amphipathic region between TM5 and TM6 that allows cations through. The cytoplasmic $\mathrm{N}$ and $\mathrm{C}$ terminal tail of the subunits can be modulated by various kinases through phosphorylation. Phosphorylation influences channel endocytosis and expression. Chemical activators may be direct channel activators or may allosterically modify channels to reduce conduction thresholds [46, 47]. The TRP family is subject to multiple single-nucleotide polymorphisms which influence channel activation. These channels are posttranslationally modified by multiple kinases: protein kinase A, protein kinase C, calcium calmodulin kinase II, and the tyrosine kinase src which prevents channel internalization and desensitization, amplifying channel conductance. Multiple pain mediators (certain inflammatory cytokines (ILB), bradykinin, proteases, and ATP) stimulate kinase activation and channel phosphorylation $[46,48,49]$.

TRPV1 channels are highly expressed on visceral spinal afferents and colocalize with nerve growth factor receptor (trk-A). They are selectively expressed on peptidergic neurons (neurons which express CGRP and SP) [42, 45]. TRPV1-activated afferents release inflammatory peptides (CGRP and SP to produce neurogenic inflammation, glutamate. TRPV1 plays a significant role in gastrointestinal inflammation, hypersensitization, but also function [50-52]. TRPV1 is expressed in bladder afferents and plays a role in micturition as well as pathologic states of interstitial cystitis [53]. Inflammatory states such as Crohn's colitis upregulate TPRV1 through kinases. Nerve growth factor and prostaglandins upregulate TRPV1 through the same mechanism [54-57]. TRPV1 has been demonstrated to be upregulated in upper gastrointestinal disorders such as gastroesophageal reflux disease and pancreatitis [58, 59]. TRPV1 remains upregulated not only in those with inflammatory bowel disease in remission but also with irritable bowel type symptoms [60]. TRPV1 is also upregulated in the CNS; inhibitors in development may need to cross the blood-brain barrier to be fully effective [45].

TRPA1 is highly expressed on primary visceral afferents and is important in visceral hypersensitivity [61]. TRPA1 is upregulated in experimental colitis and deletion of TRPA1 expression in a mouse gene "knocke-out" model reduced colitis-induced mechanical hypersensitivity [62].

3.2. Acid Sensing Ion Channels. ASIC family of ion channels is directly gated by protons as "chemoelectrical transducers." Tissue acidosis with ischemia, fractures, tumor, and incisions activates ASICs at a pH below 7.4, particularly below 7.0 [63,
64]. ASIC undergoes sustained depolarization with tissue acidosis resulting in nonadapting pain [63-65]. The channel structure consists of 6 subunits derived from 4 different genes. Each subunit is identified by the intracellular $\mathrm{C}$ and extracellular $\mathrm{N}$ terminus amino acid composition (ASIC 1a, 1b, 2a, 2b, 3, and 4) [66]. Each subtype has 2 hydrophobic transmembrane domains which flank a large extracellular loop. Although ASIC channels mainly gate protons, they are also permeable to sodium. ASIC subtypes form channel dimers which influence channel expression. Homomeric ASIC 1a dimers conduct calcium [66]. Subtypes 1, 2, and 3 are expressed on intrinsic enteric neurons, and subtypes 3 are particularly expressed on spinal extrinsic afferents [6769]. ASIC3 is up-regulated by inflammatory cytokines, metal ions, and certain neuropeptides (FMRT amide) [70]. Such neuropeptides are increased in the spinal cord and dorsal root ganglia with visceral inflammation. The endogenous kappa opioid receptor agonist, dynorphin, enhances ASIC activity and prevents desensitization [64]. Nonsteroidal antiinflammatory drugs (NSAIDs) such as diclofenac inhibit ASIC3. Toxins from the spider, Psalmopoeus cambridgei, and the sea anemone, Anthopleura elegantissima, contain ASIC inhibitors. The potassium sparing diuretic, amiloride, also inhibits multiple ASIC subtypes [71-74].

ASIC channels are more important to visceral mechanicoreceptors sensory function than cutaneous afferent function $[69,75]$. ASIC3 is also an important mediator of cardiac pain from coronary ischemia, cough, and bronchospasm from airway acidification $[76,77]$.

3.3. Voltage-Gated Sodium Channels. Sodium-gated channels can be divided into those which are tetrodotoxin sensitive ( $\mathrm{Na} 1.1-1.7)$ and resistant ( $\mathrm{Na} 1.8$ and 1.9) [78]. Tetrodotoxin-resistant channels and $\mathrm{Na} 1.7$ are mainly expressed on nociceptor sensory afferents [79]. These membrane glycoproteins have large alpha subunits and smaller beta subunits which form 9 recognizable subsets [80]. These channels have 4 domains made up of individual 6 transmembrane segments (S1-6). The sodium pore is between the fifth and sixth segments. $\mathrm{Na} 1.8$ is the most important sodium channel visceral pain and hypersensitivity [8082]. In experimental colitis, $\mathrm{Na} 1.8$ expression is increased threefold in dorsal root ganglia within that $\mathrm{T}$ 9-13 segment of the mouse. There appears to be a selective expression of this channel and not other sodium channels [83, 84]. Na 1.8 channels are also important to bladder hypersensitivity caused by chemical irritants in experimental animals. $\mathrm{Na}$ 1.8 is not important to pain of pancreatitis $[85,86]$. In the gene "knock-out" (Na 1.8 null) mouse model, experimental jejunitis failed to produce the expected hypersensitivity as measured by visceromotor responses [81, 82]. Both nerve growth factor and prostaglandins (PGE2) increased expression of tetrodotoxin-resistant sodium channels [8789]. As a result, NSAIDs indirectly block sodium channel neurotransmission by preventing PGE2-induced upregulation of sodium channels [89]. Sodium channels can be up-regulated by phosphorylation of their intracellular C terminus $[90,91]$. There are no selective Na 1.8 inhibitors which could potentially target visceral pain. There are a 
group of peptides, (conotoxins) that are a source of sodium channel blockers being developed, one of which has been approved for spinal analgesia [92].

3.4. Voltage-Gated Calcium Channels. Voltage-gated calcium channels have an alpha-1 subunit which forms the channel pore and alpha-2 delta subunit which facilitates alpha- 1 traffic to membrane surfaces [93]. There are 10 different alpha- 1 subunits and 4 alpha- 2 delta subtypes. Alpha- 2 delta subtypes 1 and 2 bind pregabalin and gabapentin. Subtype 1 is found within the medial pain matrix (anterior cingulate gyrus, insular cortex, and amygdala) [94, 95]. Alpha-2 delta subunit 1 is also expressed within the dorsal root ganglia, spinal cord, and smooth muscle of the small bowel associated with N-type calcium channels [94]. Subtype 2 is found in the periaqueductal gray, spinal cord, and diffusely throughout the CNS but not in colon or small bowel smooth muscle $[95,96]$. Pregabalin and gabapentin bind to alpha-2 delta subunits in the cytoplasm and prevent expression of calcium channels on membranes $[97,98]$. By binding and preventing expression, calcium conduction is blocked, and SP, CGRP, and glutamate cannot be released from primary afferent neurons [93]. Prevention of neurotransmitter release by pregabalin and gabapentin occurs only in pathologic states when calcium channels are being up-regulated and activated $[99,100]$. Pregabalin and gabapentin are predominantly central acting analgesic [101-103]. Gabapentinoids have been shown to reduce visceral hypersensitivity in experimental animals as well as symptoms of irritable bowel syndrome in humans [104-109]. Low-dose gabapentin and morphine reduced writhing in rats given intraperitoneal acetic acid at doses which were found to be ineffective as single agents [110]. Not only do gabapentinoids reduce nociceptive neurotransmission centrally but also improve bowel compliance to distention perhaps through blocking alpha-2 delta subunits in smooth muscle $[105,111]$.

Other calcium channels may also be involved in visceral hypersensitivity. Activation of T-type calcium channels subtype $\mathrm{Ca}(\mathrm{v}) 3.2$ on primary spinal visceral afferents has been associated with irritable bowel-like symptoms in an animal model. Symptom behaviors resolved when Ttype calcium channels were blocked [112]. In experimental bowel ischemia, mesenteric afferent neurotransmission was blocked by the L-type calcium channel blocker nifedipine [113].

3.5. Opioid Receptors. Kappa and mu opioid receptors are found on visceral afferents [114-116]. Distribution along the gastrointestinal tract indicates that endogenous opiate peptides have a modulating function for both gastrointestinal motility and secretory function. Constipating effects and dysmotility with morphine is predominantly due to actions on intrinsic enteric neurons [117]. Kappa receptors have little adverse effect on gastrointestinal motility, but doses are limited by central toxicity such as dysphoria [118-120]. The central toxicity of mu receptor agonists includes confusion, myoclonus, nausea, and vomiting which limits titration and adds symptom burden to patients with visceral pain [118]. In addition, certain mu opiates such as the enkephalin derivative DAMGO stimulate mesenteric afferents action potentials which are blocked by the opioid receptor antagonist alvimopan [121]. Mesenteric afferents respond with increasing firing rate when exposed to mu and delta receptor agonists which does not occur with selective kappa receptor agonists [122, 123]. Morphine has been shown to increase the visceral hypersensitivity and viscerosomatic referral in animal models of colitis and irritable bowel syndrome (caused by butyrate) [124].

There are 3 subtypes of kappa receptors which inhibit afferent firing and visceromotor responses to noxious colorectal distention in animal models [125-129]. In these animal models, antinociception occurs without change in colon muscle compliance [125]. Kappa opioids in animal models reduced inflammation (colitis) nociceptive responses [130-132]. Kappa receptor gene "knocked-out" mice display increasing writhe to acetic acid peritonitis compared with wild-type mice [133]. The kappa receptor agonist, CR 66, in humans selectively reduced visceral pain by esophageal distention pain tolerance but reduced somatic pain thresholds as measured by cutaneous pain [134]. Kappa receptors are important modulators of visceral pain, and it is the peripheral kappa receptor not the central receptor which is important in contradistinction to mu receptor agonists.

Kappa receptors are also found on the vagus and nodose ganglia. The kappa agonist, asimadoline, has been reported to reduce satiety and enhance postprandial gastric volumes $[135,136]$. Asimadoline has no influence on motility. Asimadoline reduced pain in a group of patients with irritable bowel syndrome [136]. However, "on-demand" asimadoline was not effective in reducing irritable bowel symptoms and worsened symptoms in diarrhea prone patients [137]. A second peripheral-restricted kappa receptor agonists, fedotozine, reduced nociceptive reflexes triggered by gut distention and reduced pain related to irritable bowel syndrome and nonulcer dyspepsia [138]. Fedotozine reversed ileus caused by acetic acid peritonitis in rats and prevented c-fos expression in the spinal cord, a measure of nociceptive traffic through the dorsal horn. C-fos was also reduced in numerous upstream brain structures demonstrating the importance of blocking nociceptive traffic to prevent neuroplasticity [139]. Fedotozine also did not influence gastrointestinal transient times. Fedotozine was ineffective in reducing symptoms and gastroparesis in diabetic patients [140]. The kappa receptor agonist ADL 10-0101 reduced pain in patients with pancreatitis without influencing heart rate, respiratory rate, oxygen saturation, or causing nausea. Analgesia appeared to be mediated by receptors outside of the CNS [141]. Other peripherally restricted kappa agonists are being developed [142].

DAMGO and morphine are more potent in reducing acetic acid peritonitis in experimental animals when given intracerebroventricular than intraperitoneal. Morphine antinociception was only partially reversed by peripherally restricted mu receptor antagonists [143]. Methylnaltrexone, a peripherally restricted mu receptor antagonist, reverses dysmotility morphine and other mu opioid agonists without reverse seen analgesia $[144,145]$. Mu receptor 
agonists such as fentanyl are reported to reduce visceromotor responses to colorectal distention in mice [146]. Neither morphine, fentanyl, or delta agonists reduced the firing ratio of mesenteric afferents, whereas kappa receptor agonists (U50,488 and fedotozine) did reduce firing rate suggesting that the opioid-induced sensitization occurs centrally and that mu receptors are either absent on extrinsic spinal afferents or do not influence action potentials [147]. These findings again indicate that central and not peripheral mu receptors are critical to modulating visceral pain; kappa agonists mediate pain relief by binding to peripheral receptors.

There is evidence that fentanyl significantly reduces visceromotor responses to a greater extent when kappa receptors are nonfunctional (kappa receptor gene "knockedout" mice) [148]. The combination of fentanyl and the kappa receptor agonist spiradoline produced dose-dependent supra-additive antinociception in an animal model involving colorectal distention. However, there appears to be a complex interplay between kappa and mu receptors. Fentanyl nociception was not blocked, but the kappa agonist antinociception was blocked by the mu receptor antagonist (b-FNA) perhaps suggesting an interaction through dimers [149]. There is little data about the benefits of combining kappa and mu receptor agonists in the clinical management of visceral pain. A recent study of human volunteers found that oxycodone which is thought to be a kappa and mu receptor agonist significantly blocked visceral pain better than morphine which has little kappa receptor activity [150]. By speculation, a combination of a mu receptor agonist and a peripherally restricted kappa receptor agonist might selectively improve visceral pain relative to a peripherally restricted kappa agonist or mu agonist alone.

3.6. Gamma Aminobutyric Acid Receptors. Gamma aminobutyric acid receptor-B (GABA-B) is involved in modulating mechanicosensory traffic through the vagus and brainstem pathways. GABA-B receptors block mechanico-sensory input but do not modulate chemosensitivity. GABA-B agonists directly influence sensory input via binding enteric receptors or by way of activating inhibitory interneurons within the CNS [151, 152]. Baclofen, a GABA-B receptor agonist, has been used in animal models to test visceral nociception. GABA-B receptors couple with $\mathrm{N}$ and $\mathrm{P} / \mathrm{Q}$ calcium channels and potassium channels which may be the mechanism of antinociception. Activation of receptors downregulates calcium channels and activates inward rectify potassium channels which improves repolarization of neurons [153155]. Baclofen in male long Evans rats reduced afferent firing from a colorectal distention. This occurs in a dose-dependent manner unrelated to smooth muscle relaxation or improved colon compliance [156, 157]. Visceromotor responses from colorectal distention are reduced by baclofen [157-159]. Baclofen also blocks the expression of c-fos in the dorsal horn to experimental colitis and capsaicin-induced bladder irritation [160, 161]. Baclofen reduced presynaptic release of SP from visceral afferents [162]. Volatile anesthetics such as halothane, isoflurane, sevoflurane sevoflurane, and propofol block visceral nociception via augmentation of GABA-B [163, 164]. Baclofen in most clinical studies was intrathecal, and the pain phenotype was largely neuropathic [165-169]. Because baclofen crosses the blood-brain barrier, benefits may be mediated centrally. There is some evidence for synergy between morphine and baclofen [166], but very little clinical data are available about the use of baclofen for visceral pain.

3.7. N-Methyl-D-Aspartate Receptors and ATP-Gated Ion Channels. N-Methyl-D-aspartate (NMDA) receptors are calcium channels activated by glutamate and are slowly desensitized once activated. These high-calcium permeable channels generate synaptic neuroplasticity, wide dynamic range neuronal responses, and gene expression within the CNS [170, 171]. NMDA receptor activation has been associated with visceral hyperalgesia [170]. Due to slow inactivation, NMDA receptors produce long-term potentiation (LTP) which generates chronic pain [172]. NMDA receptors are found on enteric extrinsic afferents from colon and bladder; these afferents release CGRP and SP once the receptor is activated [173]. NMDA receptors are also found on postsynaptic, second-order visceral afferents, within the brainstem and cortex [174-178]. Receptor activation by colon distention does not require inflammation to be present which is distinctly different from somatic NMDA receptors [179181]. Intravenous but not intrathecal memantine (an NMDA receptor blocker) reduced visceromotor responses to colorectal distention suggesting that peripheral NMDA receptors are important to antinociception [173]. The NMDA receptor blocker, MK-801, prevented dorsal horn expression of cfos to noxious colorectal distention, and another NMDA receptor blocker, APV, attenuated visceromotor responses to graded colorectal distention in a dose-dependent manner [173]. NMDA receptors within the RVM are important in modulating pain [182].

There are 2 purinergic ion channels, P2X and P2Y. P2X is an ATP-gated channel, and P2Y is a G-protein couple receptor. ATP released by cell damage, from the sympathetic nervous system or extrinsic sensory neurons, binds to P2X. A subset of P2X channels (P2X3) were upregulated in extrinsic afferents neurons by inflammatory bowel disease [183]. ATP released from the epithelial lining of the mucosa binds to several subsets of P2X (P2X3 and P2X2/3) on submucosal sensory neurons. In this way, P2X modulates peristalsis [184-186]. P2X, upregulated by interleukin-1b, was found to be a mechanism for postinfectious (jejunitis) hypersensitivity in animal models. Animals not expressing P2X subtype 7 on afferents did not develop postjejunitis visceral hypersensitivity [187].

3.8. Somatostatin and Bradykinin Receptors. Octreotide blocks somatostatin-2 receptors (SST-2). Mesenteric afferent firing rates caused by ramping jejunal pressures in Wistar rats were blunted by octreotide [188]. Reduced firing rates occurred without change in small bowel compliance. Octreotide also blocked bradykinin activation of mesenteric afferents and improved symptom behaviors of irritable bowel syndrome in animals [188-190]. Somatostatin influences motility and increases gastrointestinal transit time [191]. 
Octreotide anecdotally reduced the abdominal pain of Menetrier's disease and pain related to visceral cancer metastases $[192,193]$. Octreotide as an adjuvant to morphine reduced pain in a cohort of individuals with gastrointestinal cancers [194]. Octreotide relieved severe refractory epigastric pain in individuals with weight loss and functional bowel disorders [195]. Unfortunately, octreotide did not reduce pain from pancreatitis [196].

Bradykinin activates mesenteric afferents by way of B2 receptors and by stimulating prostaglandin production [197, 198]. The herbal preparation STW-5 (Ibergast Steigerwald Gmb H, Darmstadt, Germany) dosedependently blocks bradykinin-induced afferents discharges from mesenteric sensory neurons [199-201]. Ibergast was effective in reducing symptoms from functional dyspepsia as reported in a meta-analysis [202]. Ibergast also alters smooth muscle contraction and motility $[203,204]$.

\section{Protein Kinases}

Protein kinase A phosphorylates NMDA receptor subunit NR-1 and the transcription factor cyclic AMP (cAMP) response element binding protein (CREB). CREB upregulates the receptor for SP (neurokinin-1 receptor) [205, 206]. Colonic distention induced protein kinase A phosphorylation of NMDA receptors in the second-order postsynaptic dorsal column neurons. This was be blocked by the NMDA receptor antagonist, CNQX [37]. In the same manner, protein kinase $\mathrm{C}$ is upregulated in the gracile nuclei and in postsynaptic dorsal column neurons with visceral stimulation. Protein kinase C phosphorylates a second glutamate receptor, AMPA [207]. Formalin-induced colitis increased the activation of protein kinase $\mathrm{C}$ through attachment to neuronal membranes in the dorsal horn [208]. The mitogenic activated protein kinase family of kinases regulates neuron responses and neuroplasticity. Within this family, the extracellular signaling-related kinases (ERK 1,2) are important to visceral pain. Activation of ERK has been associated with visceral hyperalgesia [209]. ERKs couple to multiple receptors including NMDA and neurokinin-1 [210, 211]. Increased expression ERK 1, 2 in the L6-S1 mouse dorsal horn was associated with a leftward shift in visceromotor responses to colorectal distention. Blocking this kinase attenuated visceromotor responses [212].

\section{Pharmacologic Management of Visceral Pain}

Clinical trials of specific analgesics for visceral pain are sparsely published. Visceral pain is included with somatic and nociceptive pain in most clinical trials; as a result, it is difficult to determine the appropriate drug choices for visceral pain as a phenotype. The fact that there are some differences between somatic and visceral pain neurotransmission, neurotransmitters, channels, and receptors suggests that there may in fact be real differences in responses to analgesics. The use of potent opioids for inflammatory bowel disease has been associated with higher morbidity and mortality which is not reported for various types of somatic pain [213]. This may reflect the fact that patients on opioids are sicker than those who are not but this may also be related to the opioid. In a similar fashion, certain NSAIDs have been associated with poorer outcomes in inflammatory bowel disease but not for somatic pain [214, 215]. On the other hand, octreotide improves colic and symptoms from bowel obstruction better than anticholinergics; potent opioids actually may worsen colic $[216,217]$.

It is unlikely that a single analgesic or targeted agent will significantly reduce most visceral pains since multiple neurotransmitters, channels, and receptors are responsible for visceral pain. Analgesics combinations are anticipated to be better than single analgesics [218, 219]. Analgesics which are ineffective as single agents or ineffective at a particular dose may have supra-additive analgesia for visceral pain when combined with a second analgesic. Hence, singledrug trials may not predict the merit of an analgesic supraadditive analgesic combinations cannot be predicted based on single-drug activity. Analgesic dose response relationships for visceral pain may be distinctly different from somatic pain [220]. Opioids for somatic pain may in fact not work well for visceral pain and visa versa. Kappa agonists may be an example [150, 221].

Gastrointestinal motility has been assumed to be a surrogate for gastrointestinal symptoms [222]. For instance, it has been assumed that early satiety is related to reduced gastric emptying or poor proximal gastric compliance. However, kappa receptors improve satiety without changing gastrointestinal motility. Morphine and its metabolite, morphine-6-glucuronide, reduce visceral pain but increase circular muscle contraction, whereas somatostatin reduces visceral pain and reduces smooth muscle contraction [223226]. TRPV1, Na 1.8, ASIC3 targeted analgesics, and kappa receptor antagonists may have less adverse effects on gastrointestinal motility than somatostatin or mu agonists though future trials will need to confirm this speculation.

Another point is that selective visceral blocks and procedures (celiac, hypogastric, and splanchnic blocks, spinal cord stimulators, radiofrequency ablation, and midline myelotomy) needed to complement medical management [35, 227-229]. Multimodality approach for pain management requires a multidisciplinary group of experts. There is a tendency to overly rely on analgesics and refer individuals to other disciplines late when pain is poorly controlled; the cancer is widespread and patient tolerance to procedures is poor [230].

There is little doubt that central sensitization plays a role in maintaining visceral pain $[79,182,231-233]$. As a result, uncontrolled acute visceral pain will likely lead to central neuroplasticity and chronic pain despite the resolution of underlying cause for pain. Certain analgesics will need to penetrate the CNS to fully and effectively relieve pain [182].

5.1. NSAIDs and Paracetamol. Paracetamol is a weak cyclooxygenase- 2 inhibitor and a selective cyclooxygenase 3 inhibitor. It also increases brainstem serotonin neurotransmission, redirects beta-endorphin, and inhibits 5-HT 3 receptors which are pronociceptive [234-237]. Paracetamol 
is commonly used for pain, but little is known about visceral pain responses since most studies have not focused on visceral pain. In an acetic acid peritonitis model, combinations of ketoprofen plus paracetamol were synergistic at a dose ratio of 3:1 (paracetamol to ketoprofen) [238]. Several other studies involving animal models of visceral pain have confirmed benefits of NSAIDs plus paracetamol combinations $[239,240]$. In a qualitative systematic review of paracetamol plus NSAIDs combinations, combinations were superior to paracetamol alone in $85 \%$ and NSAIDs alone in $64 \%$ of studies. Ibuprofen was the most commonly used in the 21 studies reviewed. Drug combinations reduced pain by $35 \%$ and analgesic supplemented by $38 \%$. This combination was superior in gynecology surgical studies (83\%) indirectly confirming benefits for visceral pain [241].

NSAIDs are effective in reducing cancer pain in the dose-dependent fashion [242]. However, a major systematic review was not selectively focused on visceral pain [243]. Multiple studies have found that NSAIDs are effective for biliary colic and are as effective as opioids with fewer side effects [244-247]. One of the mechanisms by which NSAIDs work in renal or biliary colic may involve acetylcholine blockade. Diclofenac blocks acetylcholine-induced smooth muscle contraction [248]. NSAIDs were superior to anticholinergics in relieving biliary colic with a number 3 needed to treat and prevented progression to cholecystitis better than anticholinergic with a number 3 needed to treat $[249,250]$. In the same vein, NSAIDs are superior to anticholinergics in relieving renal colic [251]. In a meta-analysis, NSAIDs were superior to opioids in reducing renal colic [252]. Both NSAIDs and opioids provide effective analgesia in acute renal colic, but opioids are associated with a higher incidence of adverse events, particularly vomiting [252].

Nine percent of individuals with inflammatory bowel disease treated with NSAIDs deteriorate clinically and improve once the NSAID is discontinued. Loss of prostaglandin by the NSAID leads to microvascular dysfunction and sustained inflammation $[215,253,254]$.

5.2. Opioids. Opioids reduce pain; however, poor coping skills, depression, and catastrophization correlate better with dose than the degree pathology $[255,256]$. Opioids add a symptom burden associated with dysmotility [19, 257, 258]. Proactive use of laxatives and bowel softeners are needed. In addition, morphine can produce visceral hyperalgesia [124, 259] which is suppressed by gabapentinoids [260]. This may explain the advantages of this combination when treating visceral pain [219]. Features of hyperalgesia are increased pain intensity extent of pain area, or radiation with reduced responsiveness to opioid analgesia [261]. Opioid-induced hyperalgesia mimics pain associated with progression of the underlying pathological condition. Physicians unaware of this phenomenon increase the opioid dose only to worsen visceral pain. The addition of adjuvant analgesics or opioid rotation is preferred in managing opioid-induced hyperalgesia [262, 263]. Opioid functional selectivity occurs in multiple downstream signaling pathways (beta arrestin 1 and 2, kinases, and $\mathrm{G}$ proteins) caused by unique opioidreceptor conformation changes [264]. Functional selectivity is also determined by expression of certain proteins within the vicinity of the receptor. Opioid rotation will alter downstream signaling and reset the analgesic response. Paradoxically, opioid dose reduction may improve pain control [265].

Sustained release oxycodone significantly reduces chronic cancer-related visceral pain. In a multicenter prospective observational study involving 350 individuals with visceral pain, oxycodone reduced pain severity from a mean of 7 to a mean of 2.4 on a numerical rating scale ( 0 no pain, 10 severe pain) over a two-week period of time. Less than $5 \%$ of individuals continued to have severe pain at the end of 2 weeks [266]. A small randomized trial found that morphine was as effective as oxycodone in relieving pain related to pancreatic cancer [267]. Intranasal fentanyl was effective in managing acute visceral pain in the emergency department [268]. At the present time, there is little published data to give direction to the choice of opioids for visceral pain.

Combinations of analgesics which include opioids have been reported in the management of visceral pain. In an animal model, blocking TRPV1 enhanced opioid antinociception [269]. In a mouse model, the triple combination of fentanyl, trazodone, and paracetamol reduced writhing to acetic acid at doses lower than those seen with single drugs [270]. In the rat colorectal distention model, ketorolac alone was ineffective, and morphine modestly effective but the combination of ketorolac and morphine produced synergistic antinociception at dose ratios of 10:1 and 20:1 [271]. Combinations of tramadol plus morphine and tramadol plus fentanyl produced synergistic antinociception in the acetic acid writhe model but not with somatic pain (hot plate test) [272].

5.3. Adjuvant Analgesics. There is preclinical and some clinical evidence that adjuvant analgesics should be used early for visceral pain. The combination of a gabapentinoid plus opioid is a reasonable choice $[109,219]$. Octreotide reduces visceral hyperalgesia which is a logical choice to use with morphine in malignant-related bowel obstruction [189]. STW-5 blocks bradykinin receptors and pain from jejunal distention and could potentially improve opioid analgesia [200]. Baclofen reduces visceral nociception in multiple models which makes it attractive to use with opioids and nonopioid analgesics (NSAIDS or paracetamol) [156]. NMDA receptor antagonists reduced visceral pain in a different manner advanced somatic pain and may improve the opioid analgesia for visceral pain differently than from somatic or neuropathic pain [173]. Combinations of NSAIDs, paracetamol, and opioids are likely to be at least additive if not synergistic [241]. Dexmedetomidine, an alpha-2 antagonist, inhibited visceromotor responses to colorectal distention [273]. In the same manner, tricyclic antidepressants and serotonin norepinephrine reuptake inhibitors could improve visceral pain by increasing norepinephrine neurotransmission. In addition, tricyclic antidepressants inhibit sodium channels, NMDA receptors, P2X channels, and prostaglandins [274]. Combinations of antidepressants and opioids may improve visceral pain in a similar fashion as the combination does for neuropathic pain. Overall, the 
clinical evidence for drug combinations is weak and requires prospective clinical trials.

\section{Summary}

Visceral pain is mediated by unique peripheral and central pathways. Several ion channels TRPV1, Na 1.8 and ASIC3, and the kappa opioid receptor appear are particularly important to modulating pain. There are qualitative and quantitative differences in pain processing from somatic pain such that visceral pain should be considered a distinct phenotype. Drug development and treatment paradigms have to take this into consideration in cohort and randomized trials. This has been done successfully for the irritable bowel syndrome. Targeted agents are being developed to ion channels; it is unlikely that these targeted agents will produce less dysmotility than mu opioid receptor agonists. Ion channel blockers are likely to have only a modest benefit due to the multiplicity of ion channels involved in visceral pain and will have to be combined with other analgesics. There is evidence that targeted agents for TRPV1 channels improve opioid responses. Adjuvant analgesics such as the gabapentinoids are effective as single agents and should be considered early in the course of opioid therapy to prevent opioid-induced hyperalgesia and minimize opioid side effects by being "opioid sparing." Peripherally restricted kappa agonists are in development and should be combined with other analgesics and adjuvants in hope of improving pain control. Interventional procedures should be considered early to avoid chronic visceral pain poorly responsive to analgesics. Treatment algorithms have been developed for neuropathic pain based on multiple randomized trials. The same approach should be taken in the management of visceral pain.

\section{References}

[1] K. Bielefeldt, J. A. Christianson, and R. M. Davis, "Basic and clinical aspects of visceral sensation: transmission in the CNS," Neurogastroenterology and Motility, vol. 17, no. 4, pp. 488-499, 2005.

[2] G. R. Locke III, N. J. Talley, S. L. Fett, A. R. Zinsmeister, and L. J. Melton III, "Prevalence and clinical spectrum of gastroesophageal reflux: a population-based study in Olmsted County, Minnesota," Gastroenterology, vol. 112, no. 5, pp. 1448-1456, 1997.

[3] G. K. Makharia, "Understanding and treating abdominal pain and spasms in organic gastrointestinal diseases: Inflammatory bowel disease and biliary diseases," Journal of Clinical Gastroenterology, vol. 45, supplement 2, pp. S89-S93, 2011.

[4] R. K. Cross, K. T. Wilson, and D. G. Binion, "Narcotic use in patients with Crohn's disease," American Journal of Gastroenterology, vol. 100, no. 10, pp. 2225-2229, 2005.

[5] J. T. Edwards, G. L. Radford-Smith, and T. H. Florin, "Chronic narcotic use in inflammatory bowel disease patients: prevalence and clinical characteristics," Journal of Gastroenterology and Hepatology, vol. 16, no. 11, pp. 1235$1238,2001$.

[6] M. D. Long and D. A. Drossman, "Inflammatory bowel disease, irritable bowel syndrome, or what: a challenge to the functional-organic dichotomy," American Journal of Gastroenterology, vol. 105, no. 8, pp. 1796-1798, 2010.
[7] R. Spiller and K. Garsed, "Infection, inflammation, and the irritable bowel syndrome," Digestive and Liver Disease, vol. 41, no. 12, pp. 844-849, 2009.

[8] M. Simrén, J. Axelsson, R. Gillberg, H. Abrahamsson, J. Svedlund, and E. S. Björnsson, "Quality of life in inflammatory bowel disease in remission: the impact of IBS-like symptoms and associated psychological factors," American Journal of Gastroenterology, vol. 97, no. 2, pp. 389-396, 2002.

[9] R. Ansari, F. Attari, H. Razjouyan et al., "Ulcerative colitis and irritable bowel syndrome: relationships with quality of life," European Journal of Gastroenterology and Hepatology, vol. 20, no. 1, pp. 46-50, 2008.

[10] A. Caraceni and R. K. Portenoy, "An international survey of cancer pain characteristics and syndromes," Pain, vol. 82, no. 3, pp. 263-274, 1999.

[11] P. J. Christo and D. Mazloomdoost, "Cancer pain and analgesia," Annals of the New York Academy of Sciences, vol. 1138, pp. 278-298, 2008.

[12] L. A. Blackshaw, S. J. Brookes, D. Grundy, and M. Schemann, "Sensory transmission in the gastrointestinal tract," Neurogastroenterology and Motility, vol. 19, no. 1, pp. 1-3, 2007.

[13] D. Grundy, "Signalling the state of the digestive tract," Autonomic Neuroscience, vol. 125, no. 1-2, pp. 76-80, 2006.

[14] D. E. Cummings, R. S. Frayo, C. Marmonier, R. Aubert, and D. Chapelot, "Plasma ghrelin levels and hunger scores in humans initiating meals voluntarily without time- and foodrelated cues," American Journal of Physiology, vol. 287, no. 2 50-2, pp. E297-E304, 2004.

[15] A. M. Wren, L. J. Seal, M. A. Cohen et al., "Ghrelin enhances appetite and increases food intake in humans," Journal of Clinical Endocrinology and Metabolism, vol. 86, no. 12, pp. 5992-5995, 2001.

[16] J. A. Deutsch, W. G. Young, and T. J. Kalogeris, “The stomach signals satiety," Science, vol. 201, no. 4351, pp. 165-167, 1978.

[17] T. H. Moran and K. P. Kinzig, "Gastrointestinal satiety signals. II. Cholecystokinin," American Journal of Physiology, vol. 286, no. 2, pp. G183-G188, 2004.

[18] M. Buyse, M. L. Ovesjö, H. Gö̈ot et al., "Expression and regulation of leptin receptor proteins in afferent and efferent neurons of the vagus nerve," European Journal of Neuroscience, vol. 14, no. 1, pp. 64-72, 2001.

[19] M. P. Davis, "The opioid bowel syndrome: a review of pathophysiology and treatment," Journal of Opioid Management, vol. 1, no. 3, pp. 153-161, 2005.

[20] A. J. Page, T. A. O’Donnell, and L. A. Blackshaw, "Opioid modulation of ferret vagal afferent mechanosensitivity," American Journal of Physiology, vol. 294, no. 4, pp. G963G970, 2008.

[21] D. Grundy, "What activates visceral afferents?" Gut, vol. 53, no. 2, pp. ii5-ii8, 2004.

[22] D. R. Robinson and G. F. Gebhart, "Inside information: the unique features of visceral sensation," Molecular Interventions, vol. 8, no. 5, pp. 242-253, 2008.

[23] D. Grundy and M. Schemann, "Enteric nervous system," Current Opinion in Gastroenterology, vol. 22, no. 2, pp. 102110, 2006.

[24] P. R. Brumovsky and G. F. Gebhart, "Visceral organ crosssensitization-an integrated perspective," Autonomic Neuroscience, vol. 153, no. 1-2, pp. 106-115, 2010.

[25] M. A. Giamberardino and L. Vecchiet, "Visceral pain, referred hyperalgesia and outcome: new concepts," European Journal of Anaesthesiology, Supplement, vol. 12, no. 10, pp. 6166, 1995. 
[26] M. A. Pezzone, R. Liang, and M. O. Fraser, "A model of neural cross-talk and irritation in the pelvis: implications for the overlap of chronic pelvic pain disorders," Gastroenterology, vol. 128, no. 7, pp. 1953-1964, 2005.

[27] P. J. Whorwell, M. McCallum, F. H. Creed, and C. T. Roberts, "Non-colonic features of irritable bowel syndrome," Gut, vol. 27, no. 1, pp. 37-40, 1986.

[28] D. C. Sinclair, G. Weddell, and W. H. Feindel, "Referred pain and associated phenomena," Brain, vol. 71, no. 2, pp. 184$211,1948$.

[29] M. A. Giamberardino, R. Costantini, G. Affaitati et al., "Viscero-visceral hyperalgesia: characterization in different clinical models," Pain, vol. 151, no. 2, pp. 307-322, 2010.

[30] E. E. Ustinova, D. W. Gutkin, and M. A. Pezzone, "Sensitization of pelvic nerve afferents and mast cell infiltration in the urinary bladder following chronic colonic irritation is mediated by neuropeptides," American Journal of Physiology, vol. 292, no. 1, pp. F123-F130, 2007.

[31] E. E. Ustinova, M. O. Fraser, and M. A. Pezzone, "Colonic irritation in the rat sensitizes urinary bladder afferents to mechanical and chemical stimuli: an afferent origin of pelvic organ cross-sensitization," American Journal of Physiology, vol. 290, no. 6, pp. F1478-F1487, 2006.

[32] D. P. Cohen, S. R. Ikeda, and D. L. Lewis, "Neuropeptide Y and calcitonin gene-related peptide modulate voltage- gated $\mathrm{Ca} 2+$ channels in mature female rat paracervical ganglion neurons," Journal of the Society for Gynecologic Investigation, vol. 3, no. 6, pp. 342-349, 1996.

[33] J. E. Tattersall, F. Cervero, and B. M. Lumb, "Viscerosomatic neurons in the lower thoracic spinal cord of the cat: excitations and inhibitions evoked by splanchnic and somatic nerve volleys and by stimulation of brain stem nuclei," Journal of Neurophysiology, vol. 56, no. 5, pp. 1411-1423, 1986.

[34] G. J. Giesler Jr., R. L. Nahin, and A. M. Madsen, "Postsynaptic dorsal column pathway of the rat. I. Anatomical studies," Journal of Neurophysiology, vol. 51, no. 2, pp. 260-275, 1984.

[35] A. Viswanathan, A. W. Burton, A. Rekito, and I. E. McCutcheon, "Commissural myelotomy in the treatment of intractable visceral pain: technique and outcomes," Stereotactic and Functional Neurosurgery, vol. 88, no. 6, pp. 374-382, 2010.

[36] R. Becker, U. Sure, H. Bertalanffy, and M. Sindou, "Punctate midline myelotomy: a new approach in the management of visceral pain," Acta Neurochirurgica, vol. 141, no. 8, pp. 881883, 1999.

[37] W. D. Willis, E. D. Al-Chaer, M. J. Quast, and K. N. Westlund, "A visceral pain pathway in the dorsal column of the spinal cord," Proceedings of the National Academy of Sciences of the United States of America, vol. 96, no. 14, pp. 7675-7679, 1999.

[38] Y. Ren, L. Zhang, Y. Lu, H. Yang, and K. N. Westlun, "Central lateral thalamic neurons receive noxious visceral mechanical and chemical input in rats," Journal of Neurophysiology, vol. 102, no. 1, pp. 244-258, 2009.

[39] Z. Cao, X. Wu, S. Chen et al., "Anterior cingulate cortex modulates visceral pain as measured by visceromotor responses in viscerally hypersensitive rats," Gastroenterology, vol. 134, no. 2, pp. 535-543, 2008.

[40] L. P. Vera-Portocarrero, J. X. Yie, J. Kowal, M. H. Ossipov, T. King, and F. Porreca, "Descending facilitation from the rostral ventromedial medulla maintains visceral pain in rats with experimental pancreatitis," Gastroenterology, vol. 130, no. 7, pp. 2155-2164, 2006.
[41] M. O. Urban and G. F. Gebhart, "Supraspinal contributions to hyperalgesia," Proceedings of the National Academy of Sciences of the United States of America, vol. 96, no. 14, pp. 7687-7692, 1999.

[42] S. J. Hwang and J. G. Valtschanoff, "Vanilloid receptor VR1positive afferents are distributed differently at different levels of the rat lumbar spinal cord," Neuroscience Letters, vol. 349, no. 1, pp. 41-44, 2003.

[43] A. Guo, "Immunocytochemical localization of the vanilloid receptor 1 (VR1): relationship to neliropeptides, the P2X3 purinoceptor and IB4 binding sites," European Journal of Neuroscience, vol. 11, no. 3, pp. 946-958, 1999.

[44] J. G. Valtschanoff, A. Rustioni, A. Guo, and S. J. Hwang, "Vanilloid receptor VR1 is both presynaptic and postsynaptic in the superficial laminae of the rat dorsal horn," Journal of Comparative Neurology, vol. 436, no. 2, pp. 225-235, 2001.

[45] L. A. Roberts and M. Connor, "TRPV1 antagonists as a potential treatment for hyperalgesia," Recent Patents on CNS Drug Discovery, vol. 1, no. 1, pp. 65-76, 2006.

[46] A. Messeguer, R. Planells-Cases, and A. Ferrer-Montiel, "Physiology and pharmacology of the vanilloid receptor," Current Neuropharmacology, vol. 4, no. 1, pp. 1-15, 2006.

[47] P. M. Zygmunt, J. Petersson, D. A. Andersson et al., "Vanilloid receptors on sensory nerves mediate the vasodilator action of anandamide," Nature, vol. 400, no. 6743, pp. 452-457, 1999.

[48] A. Miranda, E. Nordstrom, A. Mannem, C. Smith, B. Banerjee, and J. N. Sengupta, "The role of transient receptor potential vanilloid 1 in mechanical and chemical visceral hyperalgesia following experimental colitis," Neuroscience, vol. 148, no. 4, pp. 1021-1032, 2007.

[49] A. J. Kirkup, A. M. Brunsden, and D. Grundy, "Receptors and transmission in the brain-gut axis: potential for novel therapies I. Receptors on visceral afferents," American Journal of Physiology, vol. 280, no. 5, pp. G787-G794, 2001.

[50] R. C. W. Jones Jr., L. Xu, and G. F. Gebhart, "The mechanosensitivity of mouse colon afferent fibers and their sensitization by inflammatory mediators require transient receptor potential vanilloid 1 and acid-sensing ion channel 3," Journal of Neuroscience, vol. 25, no. 47, pp. 10981-10989, 2005.

[51] A. Szallasi, D. N. Cortright, C. A. Blum, and S. R. Eid, "The vanilloid receptor TRPV1: 10 years from channel cloning to antagonist proof-of-concept," Nature Reviews Drug Discovery, vol. 6, no. 5, pp. 357-372, 2007.

[52] P. Geppetti and M. Trevisani, "Activation and sensitisation of the vanilloid receptor: role in gastrointestinal inflammation and function," British Journal of Pharmacology, vol. 141, no. 8, pp. 1313-1320, 2004.

[53] L. A. Birder, Y. Nakamura, S. Kiss et al., "Altered urinary bladder function in mice lacking the vanilloid receptor TRPV1," Nature Neuroscience, vol. 5, no. 9, pp. 856-860, 2002.

[54] C. L. Chan, P. Facer, J. B. Davis et al., "Sensory fibres expressing capsaicin receptor TRPV1 in patients with rectal hypersensitivity and faecal urgency," The Lancet, vol. 361, no. 9355, pp. 385-391, 2003.

[55] Y. Yiangou, P. Facer, N. H. Dyer et al., "Vanilloid receptor 1 immunoreactivity in inflamed human bowel," The Lancet, vol. 357, no. 9265, pp. 1338-1339, 2001.

[56] R. R. Ji, T. A. Samad, S. X. Jin, R. Schmoll, and C. J. Woolf, "p38 MAPK activation by NGF in primary sensory neurons after inflammation increases TRPV1 levels and maintains heat hyperalgesia," Neuron, vol. 36, no. 1, pp. 57-68, 2002. 
[57] L. S. Premkumar and G. P. Ahern, "Induction of vanilloid receptor channel activity by protein kinase C," Nature, vol. 408, no. 6815, pp. 985-990, 2000.

[58] P. J. Matthews, Q. Aziz, P. Facer, J. B. Davis, D. G. Thompson, and P. Anand, "Increased capsaicin receptor TRPV1 nerve fibres in the inflamed human oesophagus," European Journal of Gastroenterology and Hepatology, vol. 16, no. 9, pp. 897902, 2004.

[59] B. Adam, T. Liebregts, J. M. Gschossmann et al., "Severity of mucosal inflammation as a predictor for alterations of visceral sensory function in a rat model," Pain, vol. 123, no. 1-2, pp. 179-186, 2006.

[60] A. Akbar, Y. Yiangou, P. Facer et al., "Expression of the TRPV1 receptor differs in quiescent inflammatory bowel disease with or without abdominal pain," Gut, vol. 59, no. 6, pp. 767-774, 2010.

[61] T. K. Lapointe and C. Altier, "The role of TRPA1 in visceral inflammation and pain," Channels, vol. 5, no. 6, pp. 20-24, 2011.

[62] F. Cattaruzza, I. Spreadbury, M. Miranda-Morales, E. F. Grady, S. Vanner, and N. W. Bunnett, "Transient receptor potential ankyrin-1 has a major role in mediating visceral pain in mice," American Journal of Physiology, vol. 298, no. 1, pp. G81-G91, 2010.

[63] R. Waldmann, G. Champigny, F. Bassilana, C. Heurteaux, and M. Lazdunski, "A proton-gated cation channel involved in acid-sensing," Nature, vol. 386, no. 6621, pp. 173-177, 1997.

[64] E. Deval, X. Gasull, J. Noël et al., "Acid-sensing ion channels (ASICs): pharmacology and implication in pain," Pharmacology and Therapeutics, vol. 128, no. 3, pp. 549-558, 2010.

[65] J. Yagi, H. N. Wenk, L. A. Naves, and E. W. McCleskey, "Sustained currents through ASIC3 ion channels at the modest $\mathrm{pH}$ changes that occur during myocardial ischemia," Circulation Research, vol. 99, no. 5, pp. 501-509, 2006.

[66] E. Deval, V. Friend, C. Thirant et al., "Regulation of sensory neuron-specific acid-sensing ion channel 3 by the adaptor protein $\mathrm{Na}^{+} / \mathrm{H}^{+}$exchanger regulatory factor-1," Journal of Biological Chemistry, vol. 281, no. 3, pp. 1796-1807, 2006.

[67] Y. Yiangou, P. Facer, J. A. Smith et al., "Increased acid-sensing ion channel ASIC-3 in inflamed human intestine," European Journal of Gastroenterology and Hepatology, vol. 13, no. 8, pp. 891-896, 2001.

[68] T. Wultsch, E. Painsipp, A. Shahbazian et al., "Deletion of the acid-sensing ion channel ASIC3 prevents gastritis-induced acid hyperresponsiveness of the stomach-brainstem axis," Pain, vol. 134, no. 3, pp. 245-253, 2008.

[69] C. C. Chen, A. Zimmer, W. H. Sun, J. Hall, and M. J. Brownstein, "A role for ASIC3 in the modulation of highintensity pain stimuli," Proceedings of the National Academy of Sciences of the United States of America, vol. 99, no. 13, pp. 8992-8997, 2002.

[70] E. Deval, J. Noël, N. Lay et al., "ASIC3, a sensor of acidic and primary inflammatory pain,” The EMBO Journal, vol. 27, no. 22, pp. 3047-3055, 2008.

[71] F. Bassilana, G. Champigny, R. Waldmann, J. R. De Weille, C. Heurteaux, and M. Lazdunski, "The acid-sensitive ionic channel subunit ASIC and the mammalian degenerin MDEG form a heteromultimeric $\mathrm{H}^{+}$-gated $\mathrm{Na}^{+}$channel with novel properties," Journal of Biological Chemistry, vol. 272, no. 46, pp. 28819-28822, 1997.

[72] X. Chen, B. A. Orser, and J. F. MacDonald, "Design and screening of ASIC inhibitors based on aromatic diamidines for combating neurological disorders," European Journal of Pharmacology, vol. 648, no. 1-3, pp. 15-23, 2010.

[73] N. Voilley, J. de Weille, J. Mamet, and M. Lazdunski, "Nonsteroid anti-inflammatory drugs inhibit both the activity and the inflammation-induced expression of acid-sensing ion channels in nociceptors," Journal of Neuroscience, vol. 21, no. 20, pp. 8026-8033, 2001.

[74] N. A. Dorofeeva, O. I. Barygin, A. Staruschenko, K. V. Bolshakov, and L. G. Magazanik, "Mechanisms of nonsteroid anti-inflammatory drugs action on ASICs expressed in hippocampal interneurons," Journal of Neurochemistry, vol. 106, no. 1, pp. 429-441, 2008.

[75] A. J. Page, S. M. Brierley, C. M. Martin et al., "The ion channel ASIC1 contributes to visceral but not cutaneous mechanoreceptor function," Gastroenterology, vol. 127, no. 6, pp. 1739-1747, 2004.

[76] S. P. Sutherland, C. J. Benson, J. P. Adelman, and E. W. McCleskey, "Acid-sensing ion channel 3 matches the acid-gated current in cardiac ischemia-sensing neurons," Proceedings of the National Academy of Sciences of the United States of America, vol. 98, no. 2, pp. 711-716, 2001.

[77] B. J. Canning, D. G. Farmer, and N. Mori, "Mechanistic studies of acid-evoked coughing in anesthetized guinea pigs," American Journal of Physiology, vol. 291, no. 2, pp. R454R463, 2006.

[78] W. A. Catterall, "Cellular and molecular biology of voltagegated sodium channels," Physiological Reviews, vol. 72, supplement 4, pp. S15-S48, 1992.

[79] C. J. Woolf and M. Costigan, "Transcriptional and posttranslational plasticity and the generation of inflammatory pain," Proceedings of the National Academy of Sciences of the United States of America, vol. 96, no. 14, pp. 7723-7730, 1999.

[80] F. H. Qi, Y. L. Zhou, and G. Y. Xu, "Targeting voltage-gated sodium channels for treatment for chronic visceral pain," World Journal of Gastroenterology, vol. 17, no. 19, pp. 23572364, 2011.

[81] J. M. Laird, V. Souslova, J. N. Wood, and F. Cervero, "Deficits in visceral pain and referred hyperalgesia in Nav1.8 (SNS/PN3)-null mice," Journal of Neuroscience, vol. 22, no. 19, pp. 8352-8356, 2002.

[82] K. Hillsley, J. H. Lin, A. Stanisz et al., "Dissecting the role of sodium currents in visceral sensory neurons in a model of chronic hyperexcitability using Nav 1.8 and Nav 1.9 null mice," Journal of Physiology, vol. 576, no. 1, pp. 257-267, 2006.

[83] F. Cervero and J. M. Laird, "Role of ion channels in mechanisms controlling gastrointestinal pain pathways," Current Opinion in Pharmacology, vol. 3, no. 6, pp. 608-612, 2003.

[84] M. J. Beyak and S. Vanner, "Inflammation-induced hyperexcitability of nociceptive gastrointestinal DRG neurones: the role of voltage-gated ion channels," Neurogastroenterology and Motility, vol. 17, no. 2, pp. 175-186, 2005.

[85] N. Yoshimura, S. Seki, S. D. Novakovic et al., "The involvement of the tetrodotoxin-resistant sodium channel Nav1.8 (PN3/SNS) in a rat model of visceral pain," Journal of Neuroscience, vol. 21, no. 21, pp. 8690-8696, 2001.

[86] G. F. Gebhart, K. Bielefeldt, and N. Ozaki, "Gastric hyperalgesia and changes in voltage gated sodium channel function in the rat," Gut, vol. 51, no. 1, pp. i15-i18, 2002.

[87] M. J. Beyak, N. Ramji, K. M. Krol, M. D. Kawaja, and S. J. Vanner, "Two TTX-resistant $\mathrm{Na}^{+}$currents in mouse colonic dorsal root ganglia neurons and their role in colitis-induced 
hyperexcitability," American Journal of Physiology, vol. 287, no. 4, pp. G845-G855, 2004.

[88] M. S. Gold, L. Zhang, D. L. Wrigley, and R. J. Traub, "Prostaglandin $\mathrm{E}_{2}$ modulates TTX-R $/ \mathrm{Na}$ in rat colonic sensory neurons," Journal of Neurophysiology, vol. 88, no. 3, pp. 1512-1522, 2002.

[89] K. Ma, Q. H. Zhou, J. Chen, D. P. Du, Y. Ji, and W. Jiang, "TTX-R Na+ current-reduction by celecoxib correlates with changes in PGE2 and CGRP within rat DRG neurons during acute incisional pain," Brain Research, vol. 1209, no. C, pp. 57-64, 2008.

[90] J. S. Choi, A. Hudmon, S. G. Waxman, and S. D. DibHajj, "Calmodulin regulates current density and frequencydependent inhibition of sodium channel Nav1.8 in DRG neurons," Journal of Neurophysiology, vol. 96, no. 1, pp. 97$108,2006$.

[91] C. F. Villarreal, D. Sachs, M. I. Funez, C. A. Parada, F. de Queiroz Cunha, and S. H. Ferreira, "The peripheral pro-nociceptive state induced by repetitive inflammatory stimuli involves continuous activation of protein kinase A and protein kinase $\mathrm{C}$ epsilon and its NaV1.8 sodium channel functional regulation in the primary sensory neuron," Biochemical Pharmacology, vol. 77, no. 5, pp. 867-877, 2009.

[92] P. Li and S. Zhu, "Molecular design of new sodium channel blockers," Biochemical and Biophysical Research Communications, vol. 414, no. 2, pp. 321-325, 2011.

[93] J. D. Gale and L. A. Houghton, "Alpha 2 delta $(\alpha 2 \delta)$ ligands, gabapentin and pregabalin: what is the evidence for potential use of these ligands in irritable bowel syndrome," Frontiers in Pharmacology, vol. 2, p. 28, 2011.

[94] C. P. Taylor and R. Garrido, "Immunostaining of rat brain, spinal cord, sensory neurons and skeletal muscle for calcium channel alpha2-delta $(\alpha 2-\delta)$ type 1 protein," Neuroscience, vol. 155, no. 2, pp. 510-521, 2008.

[95] R. L. Cole, S. M. Lechner, M. E. Williams et al., "Differential distribution of voltage-gated calcium channel alpha-2 delta $(\alpha 2 \delta)$ subunit mRNA-containing cells in the rat central nervous system and the dorsal root ganglia," Journal of Comparative Neurology, vol. 491, no. 3, pp. 246-269, 2005.

[96] H. C. Gong, J. Hang, W. Kohler, L. Li, and T. Z. Su, "Tissuespecific expression and gabapentin-binding properties of calcium channel $\alpha 2 \delta$ subunit subtypes," Journal of Membrane Biology, vol. 184, no. 1, pp. 35-43, 2001.

[97] J. Hendrich, A. T. Van Minh, F. Heblich et al., "Pharmacological disruption of calcium channel trafficking by the $\alpha 2 \delta$ ligand gabapentin," Proceedings of the National Academy of Sciences of the United States of America, vol. 105, no. 9, pp. 3628-3633, 2008.

[98] P. M. Mich and W. A. Horne, "Alternative splicing of the $\mathrm{Ca}^{2+}$ channel $\beta 4$ subunit confers specificity for gabapentin inhibition of $\mathrm{Ca}_{v} 2.1$ trafficking," Molecular Pharmacology, vol. 74, no. 3, pp. 904-912, 2008.

[99] D. J. Dooley, C. M. Donovan, and T. A. Pugsley, "Stimulusdependent modulation of ${ }^{3} \mathrm{H}$ norepinephrine release from rat neocortical slices by gabapentin and pregabalin," Journal of Pharmacology and Experimental Therapeutics, vol. 295, no. 3, pp. 1086-1093, 2000.

[100] M. K. Patel, M. I. Gonzalez, S. Bramwell, R. D. Pinnock, and K. Lee, "Gabapentin inhibits excitatory synaptic transmission in the hyperalgesic spinal cord," British Journal of Pharmacology, vol. 130, no. 8, pp. 1731-1734, 2000.

[101] M. J. Field, P. J. Cox, E. Stott et al., "Identification of the $\alpha 2-\delta$ 1 subunit of voltage-calcium calcium channels as a molecular target for pain mediating the analgesic actions of pregabalin," Proceedings of the National Academy of Sciences of the United States of America, vol. 103, no. 46, pp. 17537-17542, 2006.

[102] M. J. Field, E. F. Holloman, S. McCleary, J. Hughes, and L. Singh, "Evaluation of gabapentin and S-(+)-3-isobutylgaba in a rat model of postoperative pain," Journal of Pharmacology and Experimental Therapeutics, vol. 282, no. 3, pp. 12421246, 1997.

[103] M. J. Field, R. J. Oles, A. S. Lewis, S. McCleary, J. Hughes, and L. Singh, "Gabapentin (neurontin) and S-(+)-3-isobutylgaba represent a novel class of selective antihyperalgesic agents," British Journal of Pharmacology, vol. 121, no. 8, pp. 15131522, 1997.

[104] M. Million, L. Wang, D. W. Adelson, F. Roman, L. Diop, and Y. Taché, "Pregabalin decreases visceral pain and prevents spinal neuronal activation in rats," Gut, vol. 56, no. 10, pp. 1482-1484, 2007.

[105] K. J. Lee, J. H. Kim, and S. W. Cho, "Gabapentin reduces rectal mechanosensitivity and increases rectal compliance in patients with diarrhoea-predominant irritable bowel syndrome," Alimentary Pharmacology and Therapeutics, vol. 22, no. 10, pp. 981-988, 2005.

[106] L. A. Houghton, C. Fell, P. J. Whorwell, I. Jones, D. P. Sudworth, and J. D. Gale, "Effect of a second-generation $\alpha 2 \delta$ ligand (pregabalin) on visceral sensation in hypersensitive patients with irritable bowel syndrome," Gut, vol. 56, no. 9, pp. 1218-1225, 2007.

[107] L. Diop, F. Raymond, H. Fargeau, F. Petoux, M. Chovet, and A. M. Doherty, "Pregabalin (Cl-1008) inhibits the trinitrobenzene sulfonic acid-induced chronic colonic allodynia in the rat," Journal of Pharmacology and Experimental Therapeutics, vol. 302, no. 3, pp. 1013-1022, 2002.

[108] Y. Feng, M. Cui, and W. D. Willis, "Gabapentin markedly reduces acetic acid-induced visceral nociception," Anesthesiology, vol. 98, no. 3, pp. 729-733, 2003.

[109] R. M. Stepanovíc-Petrovíc, M. A. Tomíc, S. M. Vučkovíc et al., "The antinociceptive effects of anticonvulsants in a mouse visceral pain model," Anesthesia and Analgesia, vol. 106, no. 6, pp. 1897-1903, 2008.

[110] H. Reihanikermani, M. Ansari, A. Soltani, and M. S. Meymandi, "Amitriptyline pharmacokinetics in experimental spinal cord injury in the rabbit," Indian Journal of Pharmaceutical Sciences, vol. 70, no. 6, pp. 782-785, 2008.

[111] A. Ravnefjord, M. Brusberg, H. Larsson, E. Lindström, and V. Martínez, "Effects of pregabalin on visceral pain responses and colonic compliance in rats," British Journal of Pharmacology, vol. 155, no. 3, pp. 407-416, 2008.

[112] F. Marger, A. Gelot, A. Alloui et al., "T-type calcium channels contribute to colonic hypersensitivity in a rat model of irritable bowel syndrome," Proceedings of the National Academy of Sciences of the United States of America, vol. 108, no. 27, pp. 11268-11273, 2011.

[113] W. Jiang, A. J. Kirkup, and D. Grundy, "Mast cells drive mesenteric afferent signalling during acute intestinal ischaemia," Journal of Physiology, vol. 589, no. 15, pp. 38673882, 2011.

[114] Y. Q. Ding, J. L. Li, B. Z. Lü, D. Wang, Miao-Li Zhang, and J. S. Li, "Co-localization of $\mu$-opioid receptor-like immunoreactivity with substance P-LI, calcitonin generelated peptide-LI and nitric oxide synthase- LI in vagal and glossopharyngeal afferent neurons of the rat," Brain Research, vol. 792, no. 1, pp. 149-153, 1998. 
[115] S. A. Aicher, A. Goldberg, S. Sharma, and V. M. Pickel, " $\mu$ opioid receptors present in vagal afferents and their dendritic targets in the medial nucleus tractus solitarius," Journal of Comparative Neurology, vol. 422, no. 2, pp. 181-190, 2000.

[116] K. K. Rau, R. M. Caudle, B. Y. Cooper, and R. D. Johnson, "Diverse immunocytochemical expression of opioid receptors in electrophysiologically defined cells of rat dorsal root ganglia," Journal of Chemical Neuroanatomy, vol. 29, no. 4, pp. 255-264, 2005.

[117] L. Bueno and J. Fioramonti, "Action of opiates on gastrointestinal function," Bailliere's Clinical Gastroenterology, vol. 2, no. 1 , pp. 123-139, 1988.

[118] K. Ahlbeck, "Opioids: a two-faced Janus," Current Medical Research and Opinion, vol. 27, no. 2, pp. 439-448, 2011.

[119] G. H. Rimoy, D. M. Wright, N. K. Bhaskar, and P. C. Rubin, "The cardiovascular and central nervous system effects in the human of U-62066E. A selective opioid receptor agonist," European Journal of Clinical Pharmacology, vol. 46, no. 3, pp. 203-207, 1994.

[120] K. M. Kumor, C. A. Haertzen, and R. E. Johnson, "Human psychopharmacology of ketocyclazocine as compared with cyclazocine, morphine and placebo," Journal of Pharmacology and Experimental Therapeutics, vol. 238, no. 3, pp. 960-968, 1986.

[121] D. Grundy, C. E. Booth, W. Winchester, and G. A. Hicks, "Peripheral opiate action on afferent fibres supplying the rat intestine," Neurogastroenterology and Motility, vol. 16, supplement 2, pp. 29-37, 2004.

[122] C. Eastwood and D. Grundy, "Opioid-receptor-mediated excitation of rat mesenteric afferent fibres supplying the rat jejunum," Neurogastroenterology and Motility, vol. 12, no. 6, pp. 517-522, 2000.

[123] A. C. Gray, P. J. White, and I. M. Coupar, "Characterisation of opioid receptors involved in modulating circular and longitudinal muscle contraction in the rat ileum," British Journal of Pharmacology, vol. 144, no. 5, pp. 687-694, 2005.

[124] B. Lian, L. Vera-Portocarrero, T. King, M. H. Ossipov, and F. Porreca, "Opioid-induced latent sensitization in a model of non-inflammatory viscerosomatic hypersensitivity," Brain Research C, vol. 1358, pp. 64-70, 2010.

[125] X. Su, J. N. Sengupta, and G. F. Gebhart, "Effects of kappa opioid receptor-selective agonists on responses of pelvic nerve afferents to noxious colorectal distension," Journal of Neurophysiology, vol. 78, no. 2, pp. 1003-1012, 1997.

[126] M. B. Burton and G. F. Gebhart, "Effects of kappa-opioid receptor agonists on responses to colorectal distension in rats with and without acute colonic inflammation," Journal of Pharmacology and Experimental Therapeutics, vol. 285, no. 2, pp. 707-715, 1998.

[127] J. F. Herrero and P. M. Headley, "The effects of sham and full spinalization on the systemic potency of $\mu$ - and $\kappa$-opioids on spinal nociceptive reflexes in rats," British Journal of Pharmacology, vol. 104, no. 1, pp. 166-170, 1991.

[128] P. J. Rivière, "Peripheral kappa-opioid agonists for visceral pain," British Journal of Pharmacology, vol. 141, no. 8, pp. 1331-1334, 2004.

[129] B. Kivell and T. E. Prisinzano, "Kappa opioids and the modulation of pain," Psychopharmacology, vol. 209, no. 2, pp. 109-119, 2010.

[130] G. F. Gebhart, X. Su, S. Joshi, N. Ozaki, and J. N. Sengupta, "Peripheral opioid modulation of visceral pain," Annals of the New York Academy of Sciences, vol. 909, pp. 41-50, 2000.

[131] M. A. Ackley, R. W. Hurley, D. E. Virnich, and D. L. Hammond, "A cellular mechanism for the antinociceptive effect of a kappa opioid receptor agonist," Pain, vol. 91, no. 3, pp. 377-388, 2001.

[132] J. N. Sengupta, A. Snider, X. Su, and G. F. Gebhart, "Effects of kappa opioids in the inflamed rat colon," Pain, vol. 79, no. 2-3, pp. 175-185, 1999.

[133] F. Simonin, O. Valverde, C. Smadja et al., "Disruption of the $\kappa$-opioid receptor gene in mice enhances sensitivity to chemical visceral pain, impairs pharmacological actions of the selective $\kappa$-agonist $\mathrm{U}-50,488 \mathrm{H}$ and attenuates morphine withdrawal," The EMBO Journal, vol. 17, no. 4, pp. 886-897, 1998.

[134] L. Arendt-Nielsen, A. E. Olesen, C. Staahl et al., "Analgesic efficacy of peripheral $\kappa$-opioid receptor agonist CR665 Compared to oxycodone in a multi-modal, multi-tissue experimental human pain model: selective effect on visceral pain," Anesthesiology, vol. 111, no. 3, pp. 616-624, 2009.

[135] S. Delgado-Aros, H. J. Chial, F. Cremonini et al., "Effects of asimadoline, a $\kappa$-opioid agonist, on satiation and postprandial symptoms in health," Alimentary Pharmacology and Therapeutics, vol. 18, no. 5, pp. 507-514, 2003.

[136] M. Camilleri, "Novel pharmacology: asimadoline, a $\kappa$-opioid agonist, and visceral sensation," Neurogastroenterology and Motility, vol. 20, no. 9, pp. 971-979, 2008.

[137] L. A. Szarka, M. Camilleri, D. Burton et al., "Efficacy of on-demand asimadoline, a peripheral $\kappa$-opioid agonist, in females with irritable bowel syndrome," Clinical Gastroenterology and Hepatology, vol. 5, no. 11, pp. 1268-1275, 2007.

[138] M. Delvaux, "Pharmacology and clinical experience with fedotozine," Expert Opinion on Investigational Drugs, vol. 10, no. 1, pp. 97-110, 2001.

[139] B. Bonaz, P. J. Riviere, V. Sinniger et al., "Fedotozine, a kappa-opioid agonist, prevents spinal and supra-spinal Fos expression induced by a noxious visceral stimulus in the rat," Neurogastroenterology and Motility, vol. 12, no. 2, pp. 135$147,2000$.

[140] K. L. Jones, J. M. Wishart, M. K. Berry, J.-L. Abitbol, and M. Horowitz, "Effects of fedotozine on gastric emptying and upper gastrointestinal symptoms in diabetic gastroparesis," Alimentary Pharmacology and Therapeutics, vol. 14, no. 7, pp. 937-943, 2000.

[141] J. C. Eisenach, R. Carpenter, and R. Curry, "Analgesia from a peripherally active $\kappa$-opioid receptor agonist in patients with chronic pancreatitis," Pain, vol. 101, no. 1-2, pp. 89-95, 2003.

[142] T. W. Vanderah, T. Largent-Milnes, J. Lai et al., "Novel damino acid tetrapeptides produce potent antinociception by selectively acting at peripheral $\kappa$-opioid receptors,", European Journal of Pharmacology, vol. 583, no. 1, pp. 62-72, 2008.

[143] M. Al-Khrasani, E. Lackó, P. Riba et al., "The central versus peripheral antinociceptive effects of $\mu$-opioid receptor agonists in the new model of rat visceral pain," Brain Research Bulletin, vol. 87, no. 2-3, pp. 238-243, 2012.

[144] B. Greenwood-Van Meerveld, C. J. Gardner, P. J. Little, G. A. Hicks, and D. L. Dehaven-Hudkins, "Dehaven-Hudkins DL. Preclinical studies of opioids and opioid antagonists on gastrointestinal function," Neurogastroenterology \& Motility, vol. 16, supplement 2, pp. 46-53, 2004.

[145] A. Sandner-Kiesling and J. C. Eisenach, "Pharmacology of opioid inhibition to noxious uterine cervical distension," Anesthesiology, vol. 97, no. 4, pp. 966-971, 2002.

[146] M. Larsson, S. Arvidsson, C. Ekman, and A. Bayati, "A model for chronic quantitative studies of colorectal sensitivity using balloon distension in conscious mice-effects of opioid receptor agonists," Neurogastroenterology and Motility, vol. 15, no. 4, pp. 371-381, 2003. 
[147] J. N. Sengupta, X. Su, and G. F. Gebhart, " $\kappa$, but not $\mu$ or $\delta$, opioids attenuate responses to distention of afferent fibers innervating the rat colon," Gastroenterology, vol. 111, no. 4, pp. 968-980, 1996.

[148] M. H. Larsson, A. Bayati, E. Lindström, and H. Larsson, "Involvement of $\kappa$-opioid receptors in visceral nociception in mice," Neurogastroenterology and Motility, vol. 20, no. 10, pp. 1157-1164, 2008.

[149] S. L. Briggs and R. H. Rech, "Antinociceptive interactions of micro- and kappa-opioid agonists in the colorectal distension assay in rats," Pharmacology Biochemistry and Behavior, vol. 92, no. 2, pp. 343-350, 2009.

[150] C. Staahl, L. L. Christrup, S. D. Andersen, L. Arendt-Nielsen, and A. M. Drewes, "A comparative study of oxycodone and morphine in a multi-modal, tissue-differentiated experimental pain model," Pain, vol. 123, no. 1-2, pp. 28-36, 2006.

[151] E. R. Partosoedarso, R. L. Young, and L. A. Blackshaw, " $\mathrm{GABA}_{B}$ receptors on vagal afferent pathways: peripheral and central inhibition," American Journal of Physiology Gastrointestinal and Liver Physiology, vol. 280, no. 4, pp. G658-G668, 2001.

[152] S. D. Smid, R. L. Young, N. J. Cooper, and L. A. Blackshaw, " $\mathrm{GABA}_{B} \mathrm{R}$ expressed on vagal afferent neurones inhibit gastric mechanosensitivity in ferret proximal stomac," American Journal of Physiology Gastrointestinal and Liver Physiology, vol. 281, no. 6, pp. G1494-G1501, 2001.

[153] N. Bussières and A. El Manira, "GABA ${ }_{B}$ receptor activation inhibits $\mathrm{N}$ - and P/Q-type calcium channels in cultured lamprey sensory neurons," Brain Research, vol. 847, no. 2, pp. 175-185, 1999.

[154] A. K. Filippov, A. Couve, M. N. Pangalos, F. S. Walsh, D. A. Brown, and S. J. Moss, "Heteromeric assembly of GABA ${ }_{B} \mathrm{R} 1$ and $\mathrm{GABA}_{B} \mathrm{R} 2$ receptor subunits inhibits $\mathrm{Ca}^{2+}$ current in sympathetic neurons," Journal of Neuroscience, vol. 20, no. 8, pp. 2867-2874, 2000.

[155] X. Wang and N. A. Lambert, "GABA ${ }_{B}$ receptors couple to potassium and calcium channels on identified lateral perforant pathway projection neurons," Journal of Neurophysiology, vol. 83, no. 2, pp. 1073-1078, 2000.

[156] J. N. Sengupta, B. K. Medda, and R. Shaker, "Effect of GABA receptor agonist on distension-sensitive pelvic nerve afferent fibers innervating rat colon," American Journal of Physiology Gastrointestinal and Liver Physiology, vol. 283, no. 6, pp. G1343-G1351, 2002.

[157] M. Brusberg, A. Ravnefjord, R. Martinsson, H. Larsson, V. Martinez, and E. Lindström, "The GABAB receptor agonist, baclofen, and the positive allosteric modulator, CGP7930, inhibit visceral pain-related responses to colorectal distension in rats," Neuropharmacology, vol. 56, pp. 362-367, 2009.

[158] K. Hara, Y. Saito, Y. Kirihara, Y. Yamada, S. Sakura, and Y. Kosaka, "The interaction of antinociceptive effects of morphine and GABA receptor agonists within the rat spinal cord," Anesthesia and Analgesia, vol. 89, no. 2, pp. 422-427, 1999.

[159] E. Lindström, M. Brusberg, A. Ravnefjord et al., "Oral baclofen reduces visceral pain-related pseudo-affective responses to colorectal distension in rats: relation between plasma exposure and efficacy," Scandinavian Journal of Gastroenterology, vol. 46, no. 6, pp. 652-662, 2011.

[160] L. A. Birder and W. C. de Groat, "Contribution of C-fiber afferent nerves and autonomic pathways in the urinary bladder to spinal c-fos expression induced by bladder irritation," Somatosensory and Motor Research, vol. 15, no. 1, pp. 5-12, 1998.
[161] Y. Lu and K. N. Westlund, "Effects of baclofen on colon inflammation-induced Fos, CGRP and SP expression in spinal cord and brainstem," Brain Research, vol. 889, no. 12, pp. 118-130, 2001.

[162] R. C. Riley, J. A. Trafton, S. I. Chi, and A. I. Basbaum, "Presynaptic regulation of spinal cord tachykinin signaling via $\mathrm{GABA}_{B}$ but not $\mathrm{GABA}_{A}$ receptor activation," Neuroscience, vol. 103, no. 3, pp. 725-737, 2001.

[163] Y. Wang, J. Wu, Q. Lin, H. J. Nauta, Y. Yue, and L. Fang, "Effects of general anesthetics on visceral pain transmission in the spinal cord," Molecular Pain, vol. 4, article 50, 2008.

[164] X. P. Dong and T. L. Xu, "The actions of propofol on $\gamma$-aminobutyric acid-A and glycine receptors in acutely dissociated spinal dorsal horn neurons of the rat," Anesthesia and Analgesia, vol. 95, no. 4, pp. 907-914, 2002.

[165] R. M. Herman, S. C. D'Luzansky, and R. Ippolito, "Intrathecal baclofen suppresses central pain in patients with spinal lesions. A pilot study," Clinical Journal of Pain, vol. 8, no. 4, pp. 338-345, 1992.

[166] M. Slonimski, S. E. Abram, and R. E. Zuniga, "Intrathecal baclofen in pain management," Regional Anesthesia and Pain Medicine, vol. 29, no. 3, pp. 269-276, 2004.

[167] J. P. Harmer and B. S. Larson, "Pain relief from baclofen analgesia in a neuropathic pain patient who failed opioid and pharmacotherapy: case report," Journal of Pain and Palliative Care Pharmacotherapy, vol. 16, no. 3, pp. 61-64, 2002.

[168] R. E. Zuniga, S. Perera, and S. E. Abram, "Intrathecal baclofen: a useful agent in the treatment of well-established complex regional pain syndrome," Regional Anesthesia and Pain Medicine, vol. 27, no. 1, pp. 90-93, 2002.

[169] R. E. Zuniga, C. R. Schlicht, and S. E. Abram, "Intrathecal baclofen is analgesic in patients with chronic pain," Anesthesiology, vol. 92, no. 3, pp. 876-880, 2000.

[170] E. A. Mayer and G. F. Gebhart, "Basic and clinical aspects of visceral hyperalgesia," Gastroenterology, vol. 107, no. 1, pp. 271-293, 1994.

[171] E. K. Michaelis, "Molecular biology of glutamate receptors in the central nervous system and their role in excitotoxicity, oxidative stress and aging," Progress in Neurobiology, vol. 54, no. 4, pp. 369-415, 1998.

[172] M. Randic, M. C. Jiang, K. I. Rusin, R. Cerne, and M. Kolaj, "Interactions between excitatory amino acids and tachykinins and long-term changes of synaptic responses in the rat spinal dorsal horn," Regulatory Peptides, vol. 46, no. 1-2, pp. 418-420, 1993.

[173] J. A. McRoberts, S. V. Coutinho, J. C. Marvizón et al., "Role of peripheral N-methyl-D-aspartate (NMDA) receptors in visceral nociception in rats," Gastroenterology, vol. 120, no. 7, pp. 1737-1748, 2001.

[174] H. Liu, P. W. Mantyh, and A. I. Basbaum, "NMDA-receptor regulation of substance $\mathrm{P}$ release from primary afferent nociceptors," Nature, vol. 386, no. 6626, pp. 721-724, 1997.

[175] H. Wang and V. M. Pickel, "Presence of NMDA-type glutamate receptors in cingulate corticostriatal terminals and their postsynaptic targets," Synapse, vol. 35, no. 4, pp. 300310, 2000.

[176] H. Wang, G. G. Stradtman III, X. J. Wang, and W. J. Gao, "A specialized NMDA receptor function in layer 5 recurrent microcircuitry of the adult rat prefrontal cortex," Proceedings of the National Academy of Sciences of the United States of America, vol. 105, no. 43, pp. 16791-16796, 2008.

[177] H. Wang, K. N. Gracy, and V. M. Pickel, " $\mu$-Opioid and NMDA-type glutamate receptors are often colocalized in spiny neurons within patches of the caudate-putamen 
nucleus," Journal of Comparative Neurology, vol. 412, no. 1, pp. 132-146, 1999.

[178] R. M. Chinnery, P. J. Shaw, P. G. Ince, and M. Johnson, "Autoradiographic distribution of binding sites for the nonNMDA receptor antagonist $\left[{ }^{3} \mathrm{H}\right] \mathrm{CNQX}$ in human motor cortex, brainstem and spinal cord," Brain Research, vol. 630, no. 1-2, pp. 75-81, 1993.

[179] T. Olivar and J. M. A. Laird, "Differential effects of $N$-methylD-receptor blockade on nociceptive somatic and visceral reflexes," Pain, vol. 79, no. 1, pp. 67-73, 1999.

[180] R. Kolhekar and G. F. Gebhart, "Modulation of spinal visceral nociceptive transmission by NMDA receptor activation in the rat," Journal of Neurophysiology, vol. 75, no. 6, pp. 23442353, 1996.

[181] T. Ji and R. J. Traub, "Spinal NMDA receptors contribute to neuronal processing of acute noxious and nonnoxious colorectal stimulation in the rat," Journal of Neurophysiology, vol. 86, no. 4, pp. 1783-1791, 2001.

[182] P. Anand, Q. Aziz, R. Willert, and L. van Oudenhove, "Peripheral and central mechanisms of visceral sensitization in man," Neurogastroenterology and Motility, vol. 19, supplement 1, pp. 29-46, 2007.

[183] Y. Yiangou, P. Facer, P. A. Baecker et al., "ATP-gated ion channel $\mathrm{P}_{2} \mathrm{X}_{3}$ is increased in human inflammatory bowel disease," Neurogastroenterology and Motility, vol. 13, no. 4, pp. 365-369, 2001.

[184] L. Bueno, J. Fioramonti, and R. Garcia-Villar, "Pathobiology of visceral pain: molecular mechanisms and therapeutic implications. III. Visceral afferent pathways: a source of new therapeutic targets for abdominal pain," American Journal of Physiology, vol. 278, no. 5, pp. G670-G676, 2000.

[185] M. S. Gold and G. F. Gebhart, "Nociceptor sensitization in pain pathogenesis," Nature Medicine, vol. 16, no. 11, pp. 1248-1257, 2010.

[186] M. Shinoda, B. Feng, and G. F. Gebhart, "Peripheral and central $\mathrm{P}_{2} \mathrm{X}_{3}$ receptor contributions to colon mechanosensitivity and hypersensitivity in the mouse," Gastroenterology, vol. 137, no. 6, pp. 2096-2104, 2009.

[187] C. Keating, P. Pelegrin, C. M. Martínez, and D. Grundy, " $\mathrm{P} 2 \mathrm{X}_{7}$ receptor-dependent intestinal afferent hypersensitivity in a mouse model of postinfectious irritable bowel syndrome," Journal of Immunology, vol. 187, no. 3, pp. 14671474, 2011.

[188] C. E. Booth, A. J. Kirkup, G. A. Hicks, P. P. Humphrey, and D. Grundy, "Somatostatin sst2 receptor-mediated inhibition of mesenteric afferent nerves of the jejunum in the anesthetized rat," Gastroenterology, vol. 121, no. 2, pp. 358-369, 2001.

[189] I. Schwetz, B. Naliboff, J. Munakata et al., "Anti-hyperalgesic effect of octreotide in patients with irritable bowel syndrome," Alimentary Pharmacology and Therapeutics, vol. 19, no. 1, pp. 123-131, 2004.

[190] T. K. Klooker, S. D. Kuiken, A. Lei, and G. E. Boeckxstaens, "Effect of long-term treatment with octreotide on rectal sensitivity in patients with non-constipated irritable bowel syndrome," Alimentary Pharmacology and Therapeutics, vol. 26, no. 4, pp. 605-615, 2007.

[191] L. J. O'Donnell, A. J. Watson, D. Cameron, and M. J.G. Farthing, "Effect of octreotide on mouth-to-caecum transit time in healthy subjects and in the irritable bowel syndrome," Alimentary Pharmacology and Therapeutics, vol. 4, no. 2, pp. 177-182, 1990.

[192] M. Rothenberg, R. Pai, and K. Stuart, "Successful use of octreotide to treat ménétrier's disease: a rare cause of abdominal pain, weight loss, edema, and hypoalbuminemia,"
Digestive Diseases and Sciences, vol. 54, no. 7, pp. 1403-1407, 2009.

[193] F. De Conno, L. Saita, C. Ripamonti, and V. Ventafridda, "Subcutaneous octreotide in the treatment of pain in advanced cancer patients," Journal of Pain and Symptom Management, vol. 9, no. 1, pp. 34-38, 1994.

[194] S. Befon, K. Mystakidou, M. Lyra, N. Tubanakis, and L. Vlahos, "Continuous subcutaneous octreotide in gastrointestinal cancer patients: pain control and $\beta$-endorphin levels," Anticancer Research C, vol. 20, no. 5, pp. 4039-4046, 2000.

[195] P. Ducrotte, C. Maillot, A. M. Leroi, O. Lalaude, R. Colin, and P. Denis, "Octreotide in refractory functional epigastric pain with nutritional impairment-an open study," Alimentary Pharmacology and Therapeutics, vol. 13, no. 7, pp. 969-975, 1999.

[196] P. Malfertheiner, D. Mayer, M. Büchler, J. E. DomínguezMuñoz, B. Schiefer, and H. Ditschuneit, "Treatment of pain in chronic pancreatitis by inhibition of pancreatic secretion with octreotide," Gut, vol. 36, no. 3, pp. 450-454, 1995.

[197] K. A. Maubach and D. Grundy, "The role of prostaglandins in the bradykinin-induced activation of serosal afferents of the rat jejunum in vitro," Journal of Physiology, vol. 515, part 1, pp. 277-285, 1999.

[198] H. P. Rang, S. Bevan, and A. Dray, "Chemical activation of nociceptive peripheral neurones," British Medical Bulletin, vol. 47, no. 3, pp. 534-548, 1991.

[199] M. H. Mueller, Q. Gong, O. Kelber et al., "A novel herbal preparation desensitizes mesenteric afferents to bradykinin in the rat small intestine," Neurogastroenterology and Motility, vol. 21, no. 4, pp. 467-476, 2009.

[200] M. H. Müller, C. Y. Liu, J. Glatzle et al., "STW 5 (Iberogast) reduces afferent sensitivity in the rat small intestine," Phytomedicine, vol. 13, supplement 1, pp. 100-106, 2006.

[201] C. Y. Liu, M. H. Müller, J. Glatzle et al., "The herbal preparation STW 5 (Iberogast) desensitizes intestinal afferents in the rat small intestine," Neurogastroenterology and Motility, vol. 16, no. 6, pp. 759-764, 2004.

[202] J. Melzer, W. Rösch, J. Reichling, R. Brignoli, and R. Saller, "Meta-analysis: phytotherapy of functional dyspepsia with the herbal drug preparation STW 5 (Iberogast)," Alimentary Pharmacology and Therapeutics, vol. 20, no. 11-12, pp. 12791287, 2004.

[203] A. Sibaev, B. Yuece, O. Kelber et al., "STW 5 (Iberogast) and its individual herbal components modulate intestinal electrophysiology of mice," Phytomedicine, vol. 13, supplement 5, pp. 80-89, 2006.

[204] H. P. Ammon, O. Kelber, and S. N. Okpanyi, "Spasmolytic and tonic effect of Iberogast (STW 5) in intestinal smooth muscle," Phytomedicine, vol. 13, no. 1, pp. 67-74, 2006.

[205] B. P. Bullock and J. F. Habener, "Phosphorylation of the cAMP response element binding protein CREB by cAMPdependent protein kinase A and glycogen synthase kinase-3 alters DNA- binding affinity, conformation, and increases net charge," Biochemistry, vol. 37, no. 11, pp. 3795-3809, 1998.

[206] F. T. Crump, K. S. Dillman, and A. M. Craig, "cAMPdependent protein kinase mediates activity-regulated synaptic targeting of NMDA receptors," Journal of Neuroscience, vol. 21, no. 14, pp. 5079-5088, 2001.

[207] A. S. Hughes, S. Averill, V. R. King, C. Molander, and P. J. Shortland, "Neurochemical characterization of neuronal populations expressing protein kinase $\mathrm{C}$ gamma isoform in the spinal cord and gracile nucleus of the rat," Neuroscience, vol. 153, no. 2, pp. 507-517, 2008. 
[208] Y. Zhang, K. Gong, W. Zhou et al., "Involvement of subtypes $\gamma$ and $\varepsilon$ of protein kinase $\mathrm{C}$ in colon pain induced by formalin injection," NeuroSignals, vol. 19, no. 3, pp. 142-150, 2011.

[209] A. Galan, F. Cervero, and J. M. Laird, "Extracellular signalingregulated kinase-1 and -2 (ERK 1/2) mediate referred hyperalgesia in a murine model of visceral pain," Molecular Brain Research, vol. 116, no. 1-2, pp. 126-134, 2003.

[210] R. R. Ji, H. Baba, G. J. Brenner, and C. J. Woolf, "Nociceptivespecific activation of ERK in spinal neurons contributes to pain hypersensitivity," Nature Neuroscience, vol. 2, no. 12, pp. 1114-1119, 1999.

[211] F. Karim, C. C. Wang, and R. W. Gereau, "Metabotropic glutamate receptor subtypes 1 and 5 are activators of extracellular signal-regulated kinase signaling required for inflammatory pain in mice," Journal of Neuroscience, vol. 21, no. 11, pp. 3771-3779, 2001.

[212] H. H. Lai, C. S. Qiu, L. W. Crock, M. E. Morales, T. J. Ness, and R. W. Gereau IV, "Activation of spinal extracellular signal-regulated kinases (ERK) $1 / 2$ is associated with the development of visceral hyperalgesia of the bladder," Pain, vol. 152, no. 9, pp. 2117-2124, 2011.

[213] G. R. Lichtenstein, B. G. Feagan, R. D. Cohen et al., "Serious infections and mortality in association with therapies for Crohn's disease: TREAT registry," Clinical Gastroenterology and Hepatology, vol. 4, no. 5, pp. 621-630, 2006.

[214] G. F. Bonner, "Exacerbation of inflammatory bowel disease associated with use of celecoxib," American Journal of Gastroenterology, vol. 96, no. 4, pp. 1306-1308, 2001.

[215] W. Reinisch, W. Miehsler, C. Dejaco et al., "An open-label trial of the selective cyclo-oxygenase- 2 inhibitor, rofecoxib, in inflammatory bowel disease-associated peripheral arthritis and arthralgia," Alimentary Pharmacology and Therapeutics, vol. 17, no. 11, pp. 1371-1380, 2003.

[216] C. Ripamonti, S. Mercadante, L. Groff, E. Zecca, F. De Conno, and A. Casuccio, "Role of octreotide, scopolamine butylbromide, and hydration in symptom control of patients with inoperable bowel obstruction and nasogastric tubes: a prospective randomized trial," Journal of Pain and Symptom Management, vol. 19, no. 1, pp. 23-34, 2000.

[217] S. Mercadante, C. Ripamonti, A. Casuccio, E. Zecca, and L. Groff, "Comparison of octreotide and hyoscine butylbromide in controlling gastrointestinal symptoms due to malignant inoperable bowel obstruction," Supportive Care in Cancer, vol. 8, no. 3, pp. 188-191, 2000.

[218] F. Guzman, C. Braun, R. K. Lim, G. D. Potter, and D. W. Rodgers, "Narcotic and non-narcotic analgesics which block visceral pain evoked by intra-arterial injection of bradykinin and other algesic agents," Arch Int Pharmacodyn Ther, vol. 149, pp. 571-588, 1964.

[219] M. S. Meymandi and G. Sepehri, "Gabapentin action and interaction on the antinociceptive effect of morphine on visceral pain in mice," European Journal of Anaesthesiology, vol. 25, no. 2, pp. 129-134, 2008.

[220] E. A. Gaensler, "Quantitative determination of the visceral pain threshold in man; characteristics of visceral pain, effect of inflammation and analgesics on the threshold, and relationship of analgesia to visceral spasm," The Journal of Clinical Investigation, vol. 30, no. 4, pp. 406-420, 1951.

[221] A. E. Olesen, C. Staahl, L. Arendt-Nielsen, and A. M. Drewes, "Different effects of morphine and oxycodone in experimentally evoked hyperalgesia: a human translational study," British Journal of Clinical Pharmacology, vol. 70, no. 2, pp. 189-200, 2010.
[222] K. Nelson, D. Walsh, and F. Sheehan, "Cancer and chemotherapy-related upper gastrointestinal symptoms: the role of abnormal gastric motor function and its evaluation in cancer patients," Supportive Care in Cancer, vol. 10, no. 6, pp. 455-461, 2002.

[223] H. Iwata, S. Tsuchiya, T. Nakamura, and S. Yano, "Morphine leads to contraction of the ileal circular muscle via inhibition of the nitrergic pathway in mice," European Journal of Pharmacology, vol. 574, no. 1, pp. 66-70, 2007.

[224] H. Iwata, S. Tsuchiya, K. Ueno, T. Nakamura, and S. Yano, "Morphine-6-glucuronide induces contraction of the ileal circular muscle more potently than morphine in mice," European Journal of Pharmacology, vol. 600, no. 1-3, pp. 130$132,2008$.

[225] V. D. Corleto, C. Severi, G. Romano et al., "Somatostatin receptor subtypes mediate contractility on human colonic smooth muscle cells," Neurogastroenterology and Motility, vol. 18, no. 3, pp. 217-225, 2006.

[226] Z.-F. Gu, V. D. Corleto, S. A. Mantey, D. H. Coy, P. N. Maton, and R. T. Jensen, "Somatostatin receptor subtype 3 mediates the inhibitory action of somatostatin on gastric smooth muscle cells," American Journal of Physiology, vol. 268, no. 5, part 1, pp. G739-G748, 1995.

[227] M. A. Erdek, D. E. Halpert, M. G. Fernández, and S. P. Cohen, "Assessment of celiac plexus block and neurolysis outcomes and technique in the management of refractory visceral cancer pain," Pain Medicine, vol. 11, no. 1, pp. 92$100,2010$.

[228] R. T. Nair, E. vanSonnenberg, S. Shankar et al., "Visceral and soft-tissue tumors: radiofrequency and alcohol ablation for pain relief-initial experience," Radiology, vol. 248, no. 3, pp. 1067-1076, 2008.

[229] L. Kapural, T. Deer, A. Yakovlev et al., "Technical aspects of spinal cord stimulation for managing chronic visceral abdominal pain: the results from the national survey," Pain Medicine, vol. 11, no. 5, pp. 685-691, 2010.

[230] A. Caraceni and R. K. Portenoy, "Pain management in patients with pancreatic carcinoma," Cancer, vol. 78, no. 3, supplement, pp. 639-653, 1996.

[231] S. Sarkar, Q. Aziz, C. J. Woolf, A. R. Hobson, and D. G. Thompson, "Contribution of central sensitisation to the development of non-cardiac chest pain," The Lancet, vol. 356, no. 9236, pp. 1154-1159, 2000.

[232] S. Neumann, T. P. Doubell, T. Leslie, and C. J. Woolf, "Inflammatory pain hypersensitivity mediated by phenotypic switch in myelinated primary sensory neurons," Nature, vol. 384, no. 6607, pp. 360-364, 1996.

[233] R. R. Ji and C. J. Woolf, "Neuronal plasticity and signal transduction in nociceptive neurons: Implications for the initiation and maintenance of pathological pain," Neurobiology of Disease, vol. 8, no. 1, pp. 1-10, 2001.

[234] G. G. Graham and K. F. Scott, "Mechanism of action of paracetamol," American Journal of Therapeutics, vol. 12, no. 1, pp. 46-55, 2005.

[235] G. G. Graham and K. F. Scott, "Mechanisms of action of paracetamol and related analgesics," Inflammopharmacology, vol. 11, no. 4, pp. 401-413, 2003.

[236] T. Pelissier, A. Alloui, C. Paeile, and A. Eschalier, "Evidence of a central antinociceptive effect of paracetamol involving spinal 5HT3 receptors," NeuroReport, vol. 6, no. 11, pp. 15461548, 1995.

[237] T. Pelissier, A. Alloui, F. Caussade et al., "Paracetamol exerts a spinal antinociceptive effect involving an indirect interaction with 5-hydroxytryptamine3 receptors: in vivo and in vitro 
evidence," Journal of Pharmacology and Experimental Therapeutics, vol. 278, no. 1, pp. 8-14, 1996.

[238] H. X. Qiu, J. Liu, H. Kong, Y. Liu, and X. G. Mei, "Isobolographic analysis of the antinociceptive interactions between ketoprofen and paracetamol," European Journal of Pharmacology, vol. 557, no. 2-3, pp. 141-146, 2007.

[239] H. F. Miranda, M. M. Puig, J. C. Prieto, and G. Pinardi, "Synergism between paracetamol and nonsteroidal antiinflammatory drugs in experimental acute pain," Pain, vol. 121, no. 1-2, pp. 22-28, 2006.

[240] H. F. Miranda, J. C. Prieto, M. M. Puig, and G. Pinardi, "Isobolographic analysis of multimodal analgesia in an animal model of visceral acute pain," Pharmacology Biochemistry and Behavior, vol. 88, no. 4, pp. 481-486, 2008.

[241] C. K. Ong, R. A. Seymour, P. Lirk, and A. F. Merry, "Combining paracetamol (acetaminophen) with nonsteroidal antiinflammatory drugs: a qualitative systematic review of analgesic efficacy for acute postoperative pain," Anesthesia and Analgesia, vol. 110, no. 4, pp. 1170-1179, 2010.

[242] S. Mercadante, A. Casuccio, A. Agnello, S. Pumo, J. Kargar, and S. Garofalo, "Analgesic effects of nonsteroidal antiinflammatory drugs in cancer pain due to somatic or visceral mechanisms," Journal of Pain and Symptom Management, vol. 17, no. 5, pp. 351-356, 1999.

[243] E. McNicol, S. A. Strassels, L. Goudas, J. Lau, and D. B. Carr, "NSAIDS or paracetamol, alone or combined with opioids, for cancer pain," Cochrane Database of Systematic Reviews, no. 1, Article ID CD005180, 2005.

[244] J. C. Olsen, N. A. McGrath, D. G. Schwarz, B. J. Cutcliffe, and J. L. Stern, "A double-blind randomized clinical trial evaluating the analgesic efficacy of ketorolac versus butorphanol for patients with suspected biliary colic in the emergency department," Academic Emergency Medicine, vol. 15, no. 8, pp. 718-722, 2008.

[245] G. Morgan, "Beneficial effects of NSAIDs in the gastrointestinal tract," European Journal of Gastroenterology and Hepatology, vol. 11, no. 4, pp. 393-400, 1999.

[246] D. Meyers and D. A. Feldstein, "Initial treatment of biliary colic: are NSAIDs better than opiates?" Wisconsin Medical Journal, vol. 104, no. 4, pp. 9-63, 2005.

[247] "NSAIDS for renal and biliary colic: intramuscular diclofenac," Drug and Therapeutics Bulletin, vol. 25, no. 22, pp. 85-86, 1987.

[248] S. K. Kulkarni, C. S. Patil, N. K. Jain, and A. Singh, "Modulatory effect of diclofenac on antispasmodic effect of pitofenone in cholinergic spasm," Indian Journal of Experimental Biology, vol. 42, no. 6, pp. 567-569, 2004.

[249] E. A. Akriviadis, M. Hatzigavriel, D. Kapnias, J. Kirimlidis, A. Markantas, and A. Garyfallos, "Treatment of biliary colic with diclofenac: a randomized, double-blind, placebocontrolled study," Gastroenterology, vol. 113, no. 1, pp. 225231, 1997.

[250] N. Al-Waili and K. Y. Saloom, "The analgesic effect of intravenous tenoxicam in symptomatic treatment of biliary colic: a comparison with hyoscine N-butylbromide," European Journal of Medical Research, vol. 3, no. 10, pp. 475-479, 1998.

[251] M. J. Mora Durban, J. Extramiana Cameno, M. Arrizabalaga Moreno et al., "Flubiprofen vs dipyrone combined with hyoscine: the analgesic efficacy in renal colic," Archivos Españoles de Urología, vol. 48, no. 9, pp. 867-873, 1995.

[252] A. Holdgate and T. Pollock, "Nonsteroidal anti-inflammatory drugs (NSAIDs) versus opioids for acute renal colic,"
Cochrane Database of Systematic Reviews, vol. 18, no. 2, Article ID CD004137, 2004.

[253] O. A. Hatoum, H. Miura, and D. G. Binion, "The vascular contribution in the pathogenesis of inflammatory bowel disease," American Journal of Physiology, vol. 285, no. 5, pp. H1791-H1796, 2003.

[254] O. A. Hatoum, D. G. Binion, M. F. Otterson, and D. D. Gutterman, "Acquired microvascular dysfunction in inflammatory bowel disease: loss of nitric oxide-mediated vasodilation," Gastroenterology, vol. 125, no. 1, pp. 58-69, 2003.

[255] M. K. Jensen, A. B. Thomsen, and J. Højsted, "10-year follow-up of chronic non-malignant pain patients: opioid use, health related quality of life and health care utilization," European Journal of Pain, vol. 10, no. 5, pp. 423-433, 2006.

[256] J. W. Burns and S. Bruehl, "Anger management style, opioid analgesic use, and chronic pain severity: a test of the opioiddeficit hypothesis," Journal of Behavioral Medicine, vol. 28, no. 6, pp. 555-563, 2005.

[257] A. K. Tuteja, J. Biskupiak, G. J. Stoddard, and A. G. Lipman, "Opioid-induced bowel disorders and narcotic bowel syndrome in patients with chronic non-cancer pain," Neurogastroenterology and Motility, vol. 22, no. 4, pp. 424e96, 2010.

[258] R. S. Choung, G. R. Locke III, A. R. Zinsmeister, C. D. Schleck, and N. J. Talley, "Opioid bowel dysfunction and narcotic bowel syndrome: a population-based study," American Journal of Gastroenterology, vol. 104, no. 5, pp. 1199-1204, 2009.

[259] A. Okada-Ogawa, F. Porreca, and I. D. Meng, "Sustained morphine-induced sensitization and loss of diffuse noxious inhibitory controls in dura-sensitive medullary dorsal horn neurons," Journal of Neuroscience, vol. 29, no. 50, pp. 1582815835, 2009.

[260] K. Bannister, S. Sikandar, C. S. Bauer, A. C. Dolphin, F. Porreca, and A. H. Dickenson, "Pregabalin suppresses spinal neuronal hyperexcitability and visceral hypersensitivity in the absence of peripheral pathophysiology," Anesthesiology, vol. 115, no. 1, pp. 144-152, 2011.

[261] E. Célèrier, J. P. Laulin, J. B. Corcuff, M. Le Moal, and G. Simonnet, "Progressive enhancement of delayed hyperalgesia induced by repeated heroin administration: a sensitization process," Journal of Neuroscience, vol. 21, no. 11, pp. 40744080, 2001.

[262] W. Koppert and M. Schmelz, "The impact of opioidinduced hyperalgesia for postoperative pain," Best Practice and Research, vol. 21, no. 1, pp. 65-83, 2007.

[263] P. G. Fine, "Opioid insights: opioid-induced hyperalgesia and opioid rotation," Journal of Pain and Palliative Care Pharmacotherapy, vol. 18, no. 3, pp. 75-79, 2004.

[264] K. M. Raehal, C. L. Schmid, C. E. Groer, and L. M. Bohn, "Functional selectivity at the $\mu$-opioid receptor: implications for understanding opioid analgesia and tolerance," Pharmacological Reviews, vol. 63, no. 4, pp. 1001-1019, 2011.

[265] M. S. Angst and J. D. Clark, "Opioid-induced hyperalgesia: a qualitative systematic review," Anesthesiology, vol. 104, no. 3, pp. 570-587, 2006.

[266] S. Liguori, M. Gottardi, G. Micheletto, and L. Bruno, "Pharmacological approach to chronic visceral pain. Focus on oxycodone controlled release: an open multicentric study," European Review for Medical and Pharmacological Sciences, vol. 14, no. 3, pp. 185-190, 2010. 
[267] S. Mercadante, W. Tirelli, F. David et al., "Morphine versus oxycodone in pancreatic cancer pain: a randomized controlled study," Clinical Journal of Pain, vol. 26, no. 9, pp. 794797, 2010.

[268] S. Johnston, G. J. Wilkes, J. A. Thompson, M. Ziman, and R. Brightwell, "Inhaled methoxyflurane and intranasal fentanyl for prehospital management of visceral pain in an Australian ambulance service," Emergency Medicine Journal, vol. 28, no. 1, pp. 57-63, 2011.

[269] S. R. Chen and H. L. Pan, "Loss of TRPV1-expressing sensory neurons reduces spinal $\mu$ opioid receptors but paradoxically potentiates opioid analgesia," Journal of Neurophysiology, vol. 95, no. 5, pp. 3086-3096, 2006.

[270] V. Fernández-Dueñas, R. Poveda, A. Fernández, S. Sánchez, E. Planas, and F. Ciruela, "Fentanyl-trazodone-paracetamol triple drug combination: multimodal analgesia in a mouse model of visceral pain," Pharmacology Biochemistry and Behavior, vol. 98, no. 3, pp. 331-336, 2011.

[271] T. J. Maves, P. S. Pechman, S. T. Meller, and G. F. Gebhart, "Ketorolac potentiates morphine antinociception during visceral nociception in the rat," Anesthesiology, vol. 80, no. 5, pp. 1094-1101, 1994.

[272] A. Romero, H. F. Miranda, and M. M. Puig, "Analysis of the opioid-opioid combinations according to the nociceptive stimulus in mice," Pharmacological Research, vol. 61, no. 6, pp. 511-518, 2010.

[273] F. Ulger, A. Bozkurt, S. S. Bilge et al., "The antinociceptive effects of intravenous dexmedetomidine in colorectal distension-induced visceral pain in rats: the role of opioid receptors," Anesthesia and Analgesia, vol. 109, no. 2, pp. 616$622,2009$.

[274] J. A. Micó, D. Ardid, E. Berrocoso, and A. Eschalier, "Antidepressants and pain," Trends in Pharmacological Sciences, vol. 27, no. 7, pp. 348-354, 2006. 


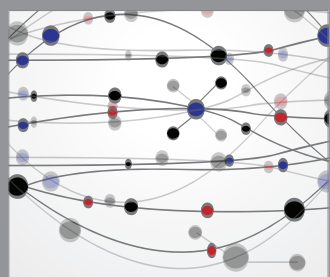

The Scientific World Journal
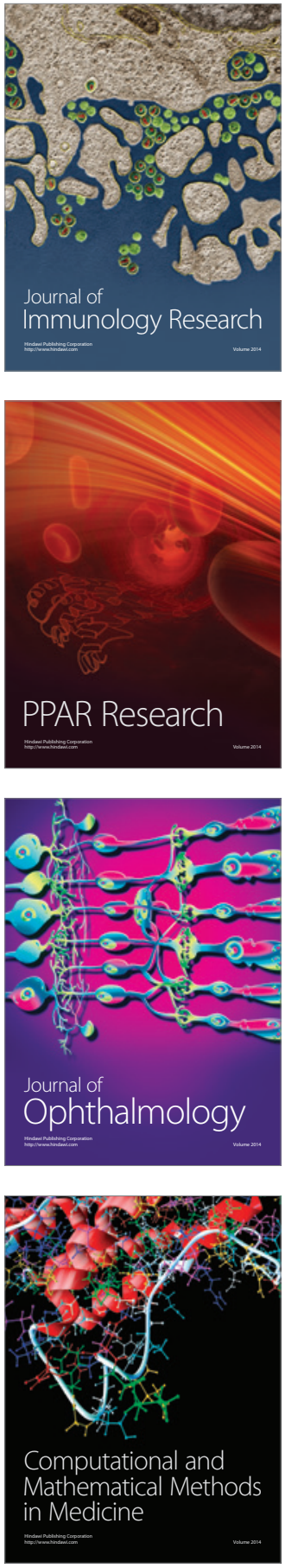

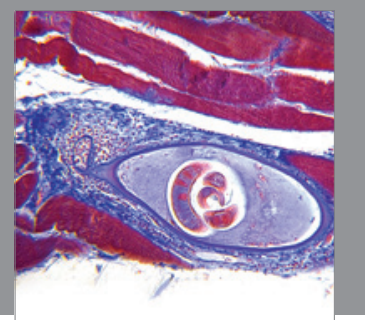

Gastroenterology

Research and Practice
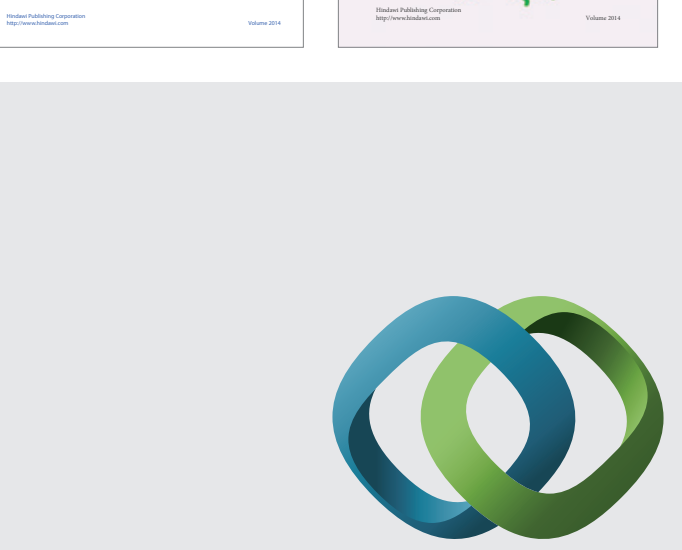

\section{Hindawi}

Submit your manuscripts at

http://www.hindawi.com
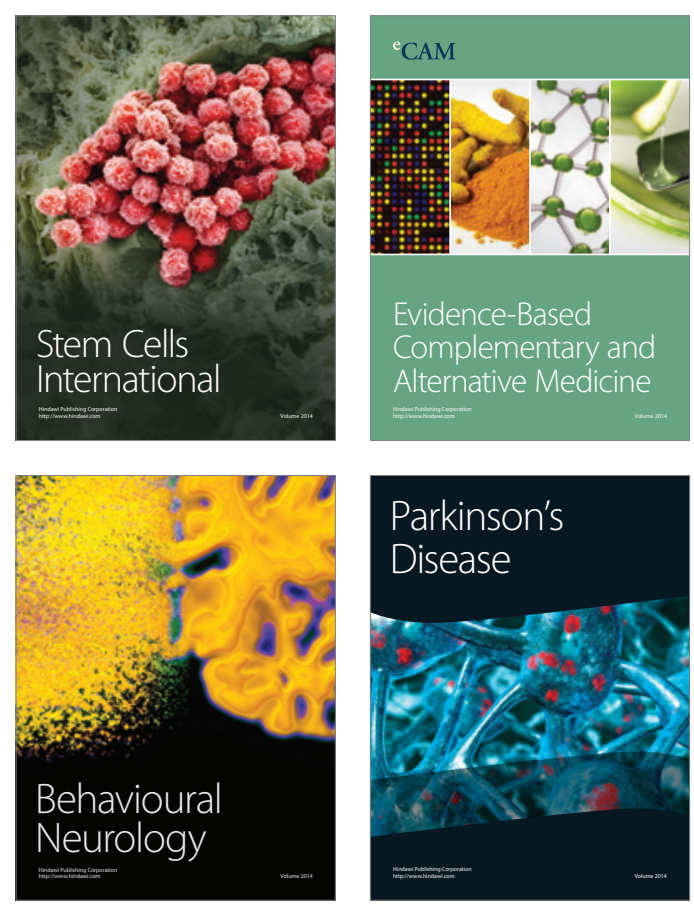

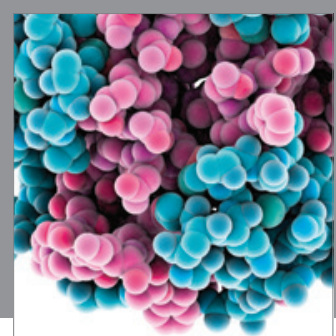

Journal of
Diabetes Research

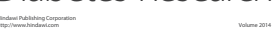

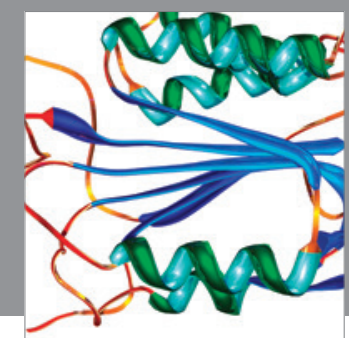

Disease Markers
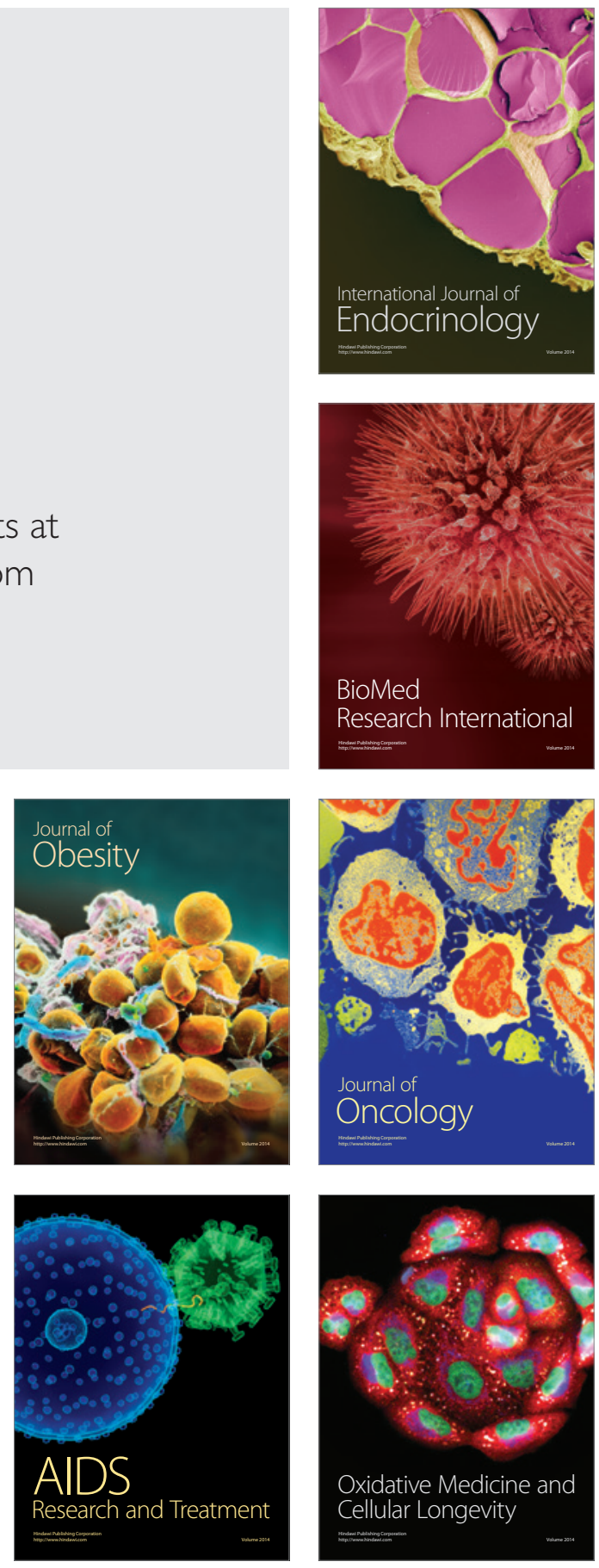